\title{
Diagnosis of Feline Infectious Peritonitis: A Review of the Current Literature
}

\author{
Sandra Felten * and Katrin Hartmann \\ Clinic of Small Animal Medicine, Center for Clinical Veterinary Medicine, Ludwig-Maximilians-Universitaet \\ Munich, Veterinaerstr. 13, 80539 Munich, Germany; hartmann@medizinische-kleintierklinik.de \\ * Correspondence: s.felten@medizinische-kleintierklinik.de
}

Received: 31 August 2019; Accepted: 13 November 2019; Published: 15 November 2019

\begin{abstract}
Feline infectious peritonitis (FIP) is a fatal disease that poses several challenges for veterinarians: clinical signs and laboratory changes are non-specific, and there are two pathotypes of the etiologic agent feline coronavirus (FCoV), sometimes referred to as feline enteric coronavirus (FECV) and feline infectious peritonitis virus (FIPV) that vary fundamentally in their virulence, but are indistinguishable by a number of diagnostic methods. This review focuses on all important steps every veterinary practitioner has to deal with and new diagnostic tests that can be considered when encountering a cat with suspected FIP with the aim to establish a definitive diagnosis. It gives an overview on all available direct and indirect diagnostic tests and their sensitivity and specificity reported in the literature in different sample material. By providing summarized data for sensitivity and specificity of each diagnostic test and each sample material, which can easily be accessed in tables, this review can help to facilitate the interpretation of different diagnostic tests and raise awareness of their advantages and limitations. Additionally, diagnostic trees depict recommended diagnostic steps that should be performed in cats suspected of having FIP based on their clinical signs or clinicopathologic abnormalities. These steps can easily be followed in clinical practice.
\end{abstract}

Keywords: diagnosis; FIP; antibody; RT-PCR; immunohistochemistry; IHC; immunocytochemistry; ICC

\section{Introduction}

Feline infectious peritonitis (FIP) is a fatal disease that occurs in domestic and wild felids worldwide. The etiologic agent, the feline coronavirus (FCoV), occurs in two distinct pathotypes that can be distinguished by their biological behavior, but not by their morphology. Some authors use different names for these two pathotypes, although they both belong to the same virus species. The feline enteric coronavirus (FECV) is highly prevalent in multi-cat environments and highly contagious-nearly $100 \%$ of cats that get in contact with FECV from feces of shedding cats become infected. However, infection is mostly asymptomatic or only causes mild and transient diarrhea [1-3]. The feline infectious peritonitis virus (FIPV), in contrast, is not infectious via the fecal-oral route, but arises by mutation from the avirulent FECV within a small percentage of infected cats and then causes the fatal disease feline infectious peritonitis (FIP) [4-6]. It is still unknown which exact genes harbor the mutation(s) leading to FIPV development. Since promising results using new drugs for treating cats with FIP have been published recently, definitive ante mortem diagnosis is crucial in order to correctly identify the population of cats which could benefit from such antiviral treatment. At the same time, definitive diagnosis is challenging, since most existing diagnostic tests cannot differentiate between FECV and FIPV, and especially in cats without body cavity effusions, it is often difficult to reach a definitive diagnosis ante mortem. 


\section{General Laboratory Testing}

FIP occurs most often in young cats under two years of age [7]. Male cats [7] and certain breeds are suggested to be overrepresented [8-10]. Clinical signs, such as anorexia, lethargy, weight loss, pyrexia, ocular and neurological signs like gait abnormalities or abnormal mentation, are non-specific [7,11-14]. The same is true for clinicopathologic abnormalities. In general, tests using effusion have much better predictive values than tests using blood [15,16]. Thus, ante mortem diagnosis of FIP is especially difficult in cats without significant effusion. Since a definitive diagnosis cannot be made based on signalment, history and clinical and laboratory signs alone, these parameters should always be evaluated as an entity and potentially in conjunction with other parameters, such as results of molecular or even more invasive diagnostic tests. In order to avoid falsely diagnosing FIP in unaffected cats, specificity is always the most important diagnostic value to consider.

\subsection{Blood}

Hematological abnormalities are very common in cats with FIP. Reported changes mainly include anemia (non-regenerative as well as regenerative anemia can be present, e.g., immune-mediated hemolytic anemia has been reported), microcytosis with or without anemia, lymphopenia (more commonly in cats with effusion), band neutrophilia (with or without segmented neutrophilia) and thrombocytopenia. Whereas microcytosis and band neutrophilia are common features of FIP in general, lymphopenia, observed in about $50 \%$ of cats with FIP, can be seen significantly more commonly in cats with effusion, but is reported only rarely in cats without effusion. The vast majority of cats with FIP also have abnormalities upon serum biochemistry. In particular, hyperproteinemia, and especially hyperglobulinemia (that can also be present without an increase in total serum protein), hypoalbuminemia (more common in cats with effusion), hyperbilirubinemia (more common in cats with effusion) and potentially, depending on organ involvement, azotemia (detected more often in cats without effusion) or increased liver enzyme activities can be present. The most common abnormality reported is hyperglobulinemia, documented in about $89 \%$ of cats with FIP [7]. These changes can occur in variable combinations but it is important to note that they absolutely are neither pathognomonic nor specific for FIP, meaning that they can occur in any cat suffering from various diseases with an inflammatory basis, which represent differential diagnoses for FIP [7,17-22]. Hyperglobulinemia in cats with FIP can occur either alone or in combination with hypoalbuminemia or hyperproteinemia. Although it has been suggested that the albumin to globulin (A:G) ratio has better diagnostic utility than the gamma-globulin or total protein concentration alone [16] and several cut-offs have been suggested to potentially rule in $(<0.4)$ or rule out $(>0.6-0.8)$ FIP $[16,19,21-23]$, the A:G ratio, as other hematological and serum biochemistry changes, should only be interpreted in conjunction with signalment, history, other laboratory parameters and possibly molecular diagnostic methods. Elevated gamma-globulin concentrations can be either polyclonal (more common) or monoclonal as differentiated by serum protein electrophoresis [24]. Thus, if a cat presents with any of the aforementioned clinicopathologic abnormalities in routine practice, these always have to be interpreted in conjunction with other clinical, laboratory or imaging findings. They might only support a suspicion of FIP if other abnormalities consistent with FIP are present as well and FIP should never be diagnosed solely on the basis of hematological or biochemical parameters.

Cats with FIP often exhibit markedly increased concentrations of acute phase proteins (APP), such as alpha-1-acid glycoprotein (AGP), serum amyloid A (SAA) or haptoglobin in serum [11,25-28]. Still, although these parameters can help in establishing a diagnosis and a negative AGP measurement can potentially exclude FIP [15], on their own, they are not pathognomonic for FIP. Increased concentrations of APP can also be found in cats with various other inflammatory conditions, neoplasia or even in healthy FECV-infected cats [25-27,29-32]. As was stated before for hematological and serum biochemical parameters, measurement of APP, such as AGP, can only be helpful when interpreted together with other abnormalities in order to provide an index of suspicion of FIP in an individual cat [28]. 


\subsection{Effusion}

The majority of cats with FIP present with effusion—specifically, pleural effusion, ascites or a combination of both $[7,13]$. Even cases of pericardial effusion have been reported [33]. The typical fluid from a cat with FIP is viscous, straw-colored, clear to moderately cloudy and usually forms clots or strings because of its high protein content [34]. Macroscopic and cytologic examination of those effusions and determination of cell count and biochemical parameters is important in order to exclude or confirm other differential diagnoses (such as lymphoma by cytology or bacterial peritonitis or pleuritis by cytology and bacterial culture); but again, changes are not specific for FIP [11,15,35-37]. Although typical effusions from cats with FIP have a high protein content, low A:G ratio $[16,38]$ and rather low total cell count [34], these findings can also occur in effusions of other etiologies. Nevertheless, in a cat which presents with typical signalment, clinical and routine laboratory abnormalities (such as for example a young cat with fever, icterus, anemia, hyperglobulinemia) and effusion, effusion analysis including cytology and bacterial culture, although not completely specific for FIP, can exclude other conditions that could confound the diagnosis and can at least help in increasing the pre-test probability for FIP.

The Rivalta's test is a cheap and quick test that can easily be performed on effusions in clinical practice, which is why, in the authors' opinion, it should be included in the diagnostic protocol in every cat with effusion. It has good sensitivity for excluding FIP (91-100\%), meaning that whenever it is negative, other potential causes for effusion are much more likely than FIP. Therefore, especially if financial concerns limit the number of diagnostic tests that can be performed, the Rivalta's test can at least be used to exclude FIP with satisfying negative predictive value with the advantage of no need for any automated analysis. However, its specificity was reported to be only $66-81 \%$ [16,39]. Since the Rivalta's test is positive most likely secondary to increased amounts of protein and inflammatory mediators in a fluid, it was originally used to differentiate transudates and exudates [40], and therefore can also be positive in effusions caused by bacterial peritonitis/pleuritis or lymphoma [16]. These conditions, however, can usually easily be diagnosed by routine cytology and culture of the effusion, which should also always be performed when analyzing an effusion sample.

Another test that relies on the abundance of proteins in effusions from cats with FIP is the measurement of the delta total nucleated cell count $(\triangle \mathrm{TNC})$ in an automated hematologic analyzer (Sysmex XT-2000iV, Sysmex Europe, Norderstedt, Denmark), measuring leucocytes in two different channels. The ratio between both channels, the $\triangle \mathrm{TNC}$, is higher in cats with FIP than in healthy cats, and its measurement showed quite good diagnostic accuracy. Using a cut-off of 1.7 for $\triangle T N C$, diagnostic sensitivity of the method was $79-90 \%$; specificity was $94-100 \%$. Higher cut-offs of 2.5 or 3.4 even increased specificity to $100 \%[15,41,42]$.

\subsection{Cerebrospinal Fluid (CSF)}

Neurological signs are more likely to occur in the population of cats with FIP without significant effusion [7]. The CSF is often sampled after diagnostic imaging of the central nervous system in order to reach a diagnosis. Upon clinicopathological examination, an increased protein content and pleocytosis can be noted in the CSF of cats with FIP [14,43-46]. CSF cytology often reveals a mixed or suppurative inflammation; mononuclear infiltration can be seen as well. Unremarkable CSF cytology can also occur [46]. However, all these changes can also be present in cats with other neurologic diseases, and some cats with neurological signs caused by FIP have normal CSF analysis [45].

\subsection{Aqueous Humor}

Eye involvement, which includes pyogranulomatous and granulomatous uveitis and chorioretinitis with a mixed uveal inflammatory cell infiltrate and predominance of B lymphocytes and plasma cells [47-49], was reported in up to $29 \%$ of cats with confirmed FIP [13]. Aqueocentesis can provide 
aqueous humor for cytological and clinicopathological testing; however, cytology is often non-diagnostic or more useful to diagnose lymphoma [50-52].

\section{Detection of Anti-FCoV Antibodies}

FCoV infection leads to the production of specific antibodies, independently of the development of FIP [53-55]. After experimental infection, serum antibodies are detectable as early as seven to 28 days after infection $[3,6,54,56-59]$.

The first assay to detect anti-FCoV antibodies was developed in 1976 [60]. By now, there are a number of different test methods: indirect immunofluorescence antibody tests (IFAT) using either FCoV [60-62] or transmissible gastroenteritis virus (TGEV) [62-65] as antigen, virus neutralization (VN) assays, enzyme-linked immunosorbent assays (ELISA) $[62,66,67]$ and rapid immunochromatographic tests (RIM) [62]. An ideal test should work on different fluids, such as serum and effusion, have high sensitivity and specificity, should allow the use of small sample quantities, provide a quantitative value and a rapid result. For excluding a diagnosis of FIP (if at all possible by antibody detection), all of these aspects matter. For FCoV screening, especially sensitivity and test rapidity are important [62].

\subsection{Blood}

In contrast to what was believed earlier, it is now well-accepted that antibody tests cannot differentiate between antibodies against FECV and FIPV, and therefore, even high antibody titers in blood are not a specific indicator for FIP $[6,68]$. Additionally, there is evidence of cross-reactivity between FCoV and other coronaviruses, such as TGEV and canine coronavirus (CCV) [68,69]. A large proportion of the cat population (up to $80 \%$ and more, especially in multi-cat households) has serum antibodies against FCoV, but most of these cats never develop FIP [54,60,70-74]. Moreover, antibodies can be detected in the serum of cats that were vaccinated against FCoV [75-77]. The significance of the presence of antibodies for diagnosing FIP in an individual cat therefore is very limited [11,16,19].

Opinions on the value of antibody measurement for the diagnosis of FIP vary, but based on the results of numerous studies, which are shown in the following paragraphs, it is the authors' opinion that antibody measurement is of no use in a cat suspected of having FIP. If antibodies are measured in a cat suspected of having FIP, then a titer should be determined in any case. Especially low and medium titers are of zero diagnostic value for the diagnosis of FIP [16,78]. Although a rising titer can sometimes be detected during progression of the disease $[55,60]$, this can also be seen in conjunction with FECV reinfection, and thus is not an indicator for FIP [70]. High and rising titers can also be found in healthy FECV-infected cats [70,73] and should never be used to confirm a suspicion of FIP. Likewise, a negative antibody test result cannot exclude FIP $[79,80]$. In end-stage FIP, especially with fulminant effusions, declining antibody titers are possible and sometimes antibody concentrations can even drop below the limit of detection $[60,68]$. Approximately $10 \%$ of cats with FIP do not have serum antibodies [16]. Most likely, the immune-mediated vasculitis in these cats leads to extravasation of blood components including antibodies into the effusion, and as a consequence, they can no longer be detected in the blood by antibody assays. Additionally, a large number of antibodies is most likely bound by the high virus load in end-stage FIP [81-83], and thus, cats with FIP without effusions can have negative serum anti-FCoV antibody titers [84]. Moreover, it has been demonstrated in longitudinal studies that in healthy cats originating from environments endemic for FIP, antibody titers can vary greatly over time $[85,86]$. Therefore, measurement of a single antibody titer at a single random time point does not provide any diagnostic information. The results of studies evaluating the performance of antibody tests for diagnosing FIP are summarized in Table 1. Sensitivity and specificity partially vary depending on the antibody cut-off titer used. Most studies reported the diagnostic value of antibody measurement compared to histopathology $[16,19,78]$. One study included cats with FIP in which the diagnosis was established upon a combination of tests performed ante mortem and histopathology [79]. Another study included cats in which FIP was suspected clinically, but the diagnosis was not confirmed [87]. The studies included control groups consisting of either healthy cats [79] and/or cats with diseases 
other than FIP $[19,79]$; in most studies, FIP was an important differential diagnosis for all control cats $[16,19,78]$.

Table 1. Studies evaluating sensitivity and specificity of the detection of serum antibodies in comparison to either histopathology, a combination of diagnostic tests or clinical suspicion of feline infectious peritonitis (FIP). Control groups either consisted of healthy cats or cats with diseases other than FIP (with or without clinical signs consistent with FIP).

\begin{tabular}{lllllll}
\hline Study & $\begin{array}{l}\text { Number of } \\
\text { Samples }\end{array}$ & $\begin{array}{l}\text { Antibody } \\
\text { Assay }\end{array}$ & Sensitivity & Specificity & $\begin{array}{l}\text { Reference } \\
\text { Standard for FIP }\end{array}$ & Control Group \\
\hline$[19]$ & $\begin{array}{l}\text { FIP }(n=39) \\
\text { Controls }(n=39)\end{array}$ & IFAT & $28-74 \%$ & $64-92 \%$ & Histopathology & $\begin{array}{l}\text { Diseases other } \\
\text { than FIP }\end{array}$ \\
\hline$[78]$ & $\begin{array}{l}\text { FIP }(n=70) \\
\text { Controls }(n=214)\end{array}$ & IFAT & $30-79 \%$ & $64-98 \%$ & Histopathology & $\begin{array}{l}\text { Diseases other } \\
\text { than FIP }\end{array}$ \\
\hline$[16]$ & $\begin{array}{l}\text { FIP }(n=97) \\
\text { Controls }(n=245)\end{array}$ & IFAT & $85 \%$ & $57 \%$ & Histopathology & $\begin{array}{l}\text { Diseases other } \\
\text { than FIP }\end{array}$ \\
\hline$[87]$ & FIP $(n=88)$ & IFAT & $100 \%$ & n. d. & Clinical suspicion & None \\
\hline [79] & $\begin{array}{l}\text { FIP }(n=19) \\
\text { Controls }(n=20)\end{array}$ & Western blot & $100 \%$ & $25-45 \%$ & $\begin{array}{l}\text { Combination of } \\
\text { tests }\end{array}$ & $\begin{array}{l}\text { Healthy or } \\
\text { diseases other } \\
\text { than FIP }\end{array}$ \\
\hline
\end{tabular}

IFAT = immunofluorescence antibody test; $\mathrm{n} . \mathrm{d}$. = not determined.

As stated before, the detection of antibodies in plasma or serum (no matter which titer) is not proof for the presence of FIP. In an attempt to increase specificity, a few years ago, an antibody assay was developed that only detected antibodies against the $\mathrm{FCoV} 7 \mathrm{~b}$ protein. This test was designed based on the erroneous assumption that FIPV, but not FECV, contains an intact $7 \mathrm{~b}$ gene. However, the test did not result in a better diagnostic performance than other antibody assays, as both cats with FIP and FECV-infected cats (healthy or suffering from other diseases) had anti-7b antibodies [79].

Nevertheless, measurement of serum antibodies is useful in guiding preventative measures and can be used for FCoV control in multi-cat households. As such, antibody detection can be performed to screen cats that are about to be newly integrated into a group, it can help to confirm successful elimination of $\mathrm{FCoV}$ in groups of cats and can guide separation of infected and non-infected cats [61]. Cats without detectable antibodies most likely do not shed FCoV with their feces $[62,70,85]$. However, fecal shedding has been observed in experimentally infected cats despite the absence of serum antibodies [54].

\subsection{Effusion}

The diagnostic utility of anti-FCoV antibody detection in effusion has been examined in a few studies as well $[16,87]$. In cats with FIP confirmed by histopathology, antibody detection in effusion had a sensitivity of $86 \%$ and a specificity of $85 \%$ [16]. Although these numbers sound more promising than what is reported for the antibody detection in serum, it has to be emphasized that the diagnostic value of antibody measurement in both serum and effusion is similarly low and bears the same limitations. Additionally, it has to be mentioned that many studies on antibody detection in effusion suffer from some limitations, such as inclusion of cats without a definitive diagnosis of FIP. For example, a comparison of antibody detection in serum and effusion in cats with a clinical suspicion of FIP revealed good concordance of test results in both body fluids; the antibody titer measured in effusion was lower than that determined in serum in $23 \%$ of cats. However, FIP was not definitively confirmed in any of the cats included [87]. The same was true for a study in which FIP was suspected in 61 cats based on different effusion features (cases had to fulfill all or most of the criteria for FIP diagnosis given by the European Advisory Board of Cat Diseases recommendations of 2009 [88]), but the diagnosis was not definitively confirmed in any of the cats. Detection of anti-FCoV antibodies had a sensitivity of $84 \%$. The fact that 18 cats without detectable antibodies were positive for FCoV RNA in their effusion demonstrated that anti-FCoV antibody detection alone has only limited diagnostic value [89]. 
One study even found an inverse correlation between FCoV antibody titers and FCoV viral load; therefore, false negative antibody results can occur in cats with high viral RNA loads [81]. In conclusion, antibody detection in effusion is not more useful for the diagnosis of FIP than antibody detection in serum (Table 2).

Table 2. Sensitivity and specificity from different studies evaluating the detection of antibodies in effusion for the diagnosis of feline infectious peritonitis (FIP) compared to histopathology, a combination of tests or a clinical suspicion of FIP. The control group of the first study consisted of cats with diseases other than FIP (with clinical signs consistent with FIP).

\begin{tabular}{llllllll}
\hline Study & Sample Type & $\begin{array}{l}\text { Number of } \\
\text { Samples }\end{array}$ & $\begin{array}{l}\text { Antibody } \\
\text { Assay }\end{array}$ & Sensitivity & Specificity & $\begin{array}{l}\text { Reference } \\
\text { Standard for FIP }\end{array}$ & $\begin{array}{l}\text { Control } \\
\text { Group }\end{array}$ \\
\hline$[16]$ & $\begin{array}{l}\text { Ascites or } \\
\text { pleural effusion }\end{array}$ & $\begin{array}{l}\text { FIP }(n=119) \\
\text { Controls }(n=74)\end{array}$ & IFAT & $86 \%$ & $85 \%$ & Histopathology & $\begin{array}{l}\text { Diseases other } \\
\text { than FIP }\end{array}$ \\
\hline$[87]$ & Ascites & FIP $(n=88)$ & IFAT & $100 \%$ & n. d. & Clinical suspicion & None \\
\hline$[89]$ & $\begin{array}{l}\text { Ascites or } \\
\text { pleural effusion }\end{array}$ & FIP $(n=61)$ & IFAT & $84 \%$ & n. d. & $\begin{array}{l}\text { Combination of } \\
\text { tests (according to } \\
\text { ABCD guidelines) }\end{array}$ & None \\
\hline
\end{tabular}

$\mathrm{ABCD}=$ European Advisory Board on Cat Diseases; IFAT = immunofluorescence antibody test; $\mathrm{n}$. $\mathrm{d}$. = not determined.

\subsection{CSF}

While the detection of anti-FCoV antibodies in the CSF of cats with neurologic FIP was first regarded as useful for the diagnosis [45], subsequent investigations including larger and more appropriate control groups showed that the detection of antibodies in the CSF, as in serum and effusion, is not suitable for a definitive ante mortem diagnosis of FIP [46]. Sensitivity and specificity were calculated with histopathology as reference standard; the control groups either consisted of only cats with any kind of neurologic disease [45] or of a combination of cats with neurologic and non-neurologic disorders [46] (Table 3). A recent study included cats with neurological signs suggested to be caused by FIP, although the diagnosis was not confirmed by histopathology. In this study, CSF from a large number of cats was analyzed and revealed a low sensitivity of the detection of FCoV antibodies for the diagnosis of FIP. However, the authors hypothesized that the detection of FCoV RNA in CSF would confirm FIP and, as they found FCoV RNA in all cats with a CSF antibody titer of 1:640 or higher, based on these results concluded that a CSF antibody titer of 1:640 or higher might be confirmatory for FIP. However, the results are of limited value, as control cats were not included in the study and the diagnosis of FIP was not confirmed [90].

Table 3. Sensitivity and specificity from different studies evaluating the detection of antibodies in cerebrospinal fluid (CSF) for the diagnosis of feline infectious peritonitis (FIP) compared to histopathology. Control groups consisted of cats with diseases other than FIP (with or without neurological signs).

\begin{tabular}{|c|c|c|c|c|c|c|}
\hline Study & Number of Samples & $\begin{array}{l}\text { Antibody } \\
\text { Assay }\end{array}$ & Sensitivity & Specificity & $\begin{array}{l}\text { Reference } \\
\text { Standard for FIP }\end{array}$ & Control Group \\
\hline [45] & FIP without neurological signs $(n=8)$ & IFAT & $0 \%$ & n. d. & Histopathology & None \\
\hline [46] & $\begin{array}{l}\text { FIP without neurological signs }(n=13) \\
\text { Controls without neurological signs }(n=15)\end{array}$ & IFAT & $31 \%$ & $100 \%$ & Histopathology & $\begin{array}{l}\text { Diseases other } \\
\text { than FIP }\end{array}$ \\
\hline [46] & $\begin{array}{l}\text { FIP with neurological signs }(n=10) \\
\text { Controls with neurological signs }(n=29)\end{array}$ & IFAT & $60 \%$ & $93 \%$ & Histopathology & $\begin{array}{l}\text { Diseases other } \\
\text { than FIP }\end{array}$ \\
\hline [90] & FIP with neurological signs $(n=271)$ & IFAT & $10 \%$ & n. d. & Clinical suspicion & None \\
\hline
\end{tabular}


Due to the correlation of serum and CSF antibodies and the fact that antibody titers measured in serum were always higher than those measured in CSF, extravasation of antibodies from serum into the CSF across an impaired blood-brain barrier is discussed as the most likely explanation for the detection of anti-FCoV antibodies in the CSF of cats without FIP. Another possibility seems to be local antibody production by migrating B lymphocytes in cats with FECV infection [46], whereas there is no evidence for specific antibody production by intrathecal B lymphocytes [44].

\section{Detection of Immune Complexes}

The production of non-protective antibodies and formation of immune complexes are discussed as key features for the development of typical immune-mediated lesions in cats with FIP [56,91-97], and circulating immune complexes could be detected in serum and effusion of FCoV-infected cats [53, 54,95,98-100]. Compared to histopathology as reference standard, the detection of immune complexes in serum via competitive enzyme-linked immunosorbent assay (ELISA) had a sensitivity of $48 \%$ and a specificity of $91 \%$ for diagnosing FIP (Table 4). Control cats in that study were suspected of having FIP, but another disease was diagnosed [16].

Table 4. Sensitivity and specificity from a study evaluating the detection of immune complexes for the diagnosis of feline infectious peritonitis (FIP) compared to histopathology. The control group consisted of cats with diseases other than FIP (with clinical signs consistent with FIP).

\begin{tabular}{llllllll}
\hline Study & $\begin{array}{l}\text { Sample } \\
\text { Material }\end{array}$ & $\begin{array}{l}\text { Number of } \\
\text { Samples }\end{array}$ & Assay & Sensitivity & Specificity & $\begin{array}{l}\text { Reference } \\
\text { Standard for FIP }\end{array}$ & Control Cats \\
\hline$[16]$ & Serum & $\begin{array}{l}\text { FIP }(n=29) \\
\text { Controls }(n=83)\end{array}$ & $\begin{array}{l}\text { Competitive } \\
\text { ELISA }\end{array}$ & $48 \%$ & $91 \%$ & Histopathology & $\begin{array}{l}\text { Diseases other } \\
\text { than FIP }\end{array}$ \\
\hline
\end{tabular}

ELISA = enzyme-linked immunosorbent assay.

Other investigations confirmed the presence of FCoV-specific immune complexes in healthy cats without FIP $[53,54]$. It has been suggested that also in FECV-infected cats, immune complexes seem to circulate, although for a limited period of time only [99]. In conclusion, detection of immune complexes is not useful for the diagnosis of FIP [16].

\section{Detection of FCoV Antigen in Macrophages by Immunostaining}

Monocytes/macrophages are the target cells for FIPV replication [91,101-105]. Both FECV and FIPV can replicate within monocytes/macrophages and lead to monocyte-associated viremia [54,106-109]. For a long time, it was believed that only FIPV can replicate in a sufficient way that allows intracellular antigen detection via immunologic methods [88], in which antibodies bind to FCoV antigen within its target cells and enzymatic reactions or fluorescent conjugates result in coloring of the antigen. However, this assumption has been questioned recently, as a number of studies, which will be shown in the following paragraphs, have detected positive immunostaining also in cats not suffering from FIP. The nature of these false positive results remains unclear; it is possible that not only FIPV, but also FECV can be detected intracellularly in macrophages via immunologic staining methods.

\subsection{Tissue}

Immunohistochemical staining of FCoV antigen within characteristic histopathological tissue lesions is still considered gold standard for the diagnosis of FIP [11-13,102,110]. When first reported in 1989, a study described the detection of FCoV antigen in epithelial cells of a cat's nictitating membrane by immunofluorescence staining of impression smears [111]. A different study used an avidin-biotin-complex $(\mathrm{ABC})$ method to detect $\mathrm{FCoV}$ antigen in tissue samples of various organs by enzymatic color change [112]. Since then, successful immunostaining of antigen has been demonstrated several times in different organs from cats with FIP-either by indirect immunofluorescence $[113,114]$ or by immunohistochemistry (IHC) within tissue macrophages in histopathologically evident tissue 
lesions caused by FIP $[102,115,116]$. IHC was shown to have excellent sensitivity of $97-100 \%$ in cats with histopathologically confirmed FIP $[115,116]$ and also specificity of up to $100 \%$ to exclude FIP in control cats with other diseases diagnosed by histopathology [115]. An overview of studies reporting the detection of FCoV antigen in tissue samples is shown in Table 5.

Table 5. Sensitivity and specificity from different studies evaluating immunostaining for the detection of feline coronavirus (FCoV) antigen in tissues samples. Feline infectious peritonitis (FIP) was confirmed either by histopathology alone or in combination with immunohistochemistry (IHC) of tissue samples. Control groups, if present, consisted of cats with diseases other than FIP with clinical signs consistent with FIP.

\begin{tabular}{|c|c|c|c|c|c|c|c|}
\hline Study & $\begin{array}{l}\text { Sample } \\
\text { Material }\end{array}$ & $\begin{array}{l}\text { Number of } \\
\text { Samples }\end{array}$ & Assay & Sensitivity & Specificity & $\begin{array}{l}\text { Reference Standard } \\
\text { for FIP }\end{array}$ & Control Cats \\
\hline [115] & $\begin{array}{l}\text { Various } \\
\text { tissues }\end{array}$ & $\begin{array}{l}\text { FIP }(n=102) \\
\text { Controls }(n=6)\end{array}$ & IHC & $98 \%$ & $100 \%$ & Histopathology & $\begin{array}{l}\text { Diseases other } \\
\text { than FIP }\end{array}$ \\
\hline [117] & TCB liver & $\operatorname{FIP}(n=25)$ & IHC & $24 \%$ & n. d. & $\begin{array}{l}\text { Histopathology/IHC } \\
\text { of other organs }\end{array}$ & None \\
\hline [117] & $\begin{array}{l}\text { TCB } \\
\text { kidney }\end{array}$ & $\operatorname{FIP}(n=18)$ & IHC & $31 \%$ & n. d. & $\begin{array}{l}\text { Histopathology/IHC } \\
\text { of other organs }\end{array}$ & None \\
\hline [117] & FNA liver & $\operatorname{FIP}(n=22)$ & ICC & $17-31 \%$ & n. d. & $\begin{array}{l}\text { Histopathology/IHC } \\
\text { of other organs }\end{array}$ & None \\
\hline [117] & $\begin{array}{l}\text { FNA } \\
\text { kidney }\end{array}$ & $\operatorname{FIP}(n=24)$ & ICC & $11-20 \%$ & n. d. & $\begin{array}{l}\text { Histopathology/IHC } \\
\text { of other organs }\end{array}$ & None \\
\hline [116] & $\begin{array}{l}\text { Various } \\
\text { tissues }\end{array}$ & FIP $(n=26)$ & IHC & $100 \%$ & n. d. & Histopathology & None \\
\hline [118] & $\begin{array}{l}\text { FNA } \\
\text { mesenteric } \\
\text { lymph } \\
\text { nodes }\end{array}$ & $\begin{array}{l}\text { FIP }(n=30) \\
\text { Controls }(n=11)\end{array}$ & ICC & $53 \%$ & $91 \%$ & $\begin{array}{l}\text { Histopathology/IHC } \\
\text { of other organs }\end{array}$ & $\begin{array}{l}\text { Diseases other } \\
\text { than FIP }\end{array}$ \\
\hline
\end{tabular}

FNA = fine-needle aspirate; ICC = immunocytochemistry; $n$. d. = not determined; TCB = Tru-cut biopsies.

In many cases, IHC can only be performed post mortem, because ante mortem tissue sample collection via laparotomy or laparoscopy is an invasive procedure that bears several risks for the sick cat. Many different organs have to be sampled due to the fact that FCoV antigen is variably distributed within the FIP-induced tissue lesions [102]. Unfortunately, the use of liver, kidney or lymph node samples obtained by minimally invasive ultrasound-guided fine-needle aspirates (FNA) or Tru-cut biopsies (TCB) for immunocytochemical or immunohistochemical staining has been shown to result in low sensitivities $[117,118]$. A possible explanation for this could be inadequate material obtained for analysis due to cellular damage [119]. Additionally, a false positive immunocytochemical result was found in a mesenteric lymph node sample, resulting in a specificity of only $91 \%$ [118]. Therefore, immunocytochemistry (ICC) or IHC on samples obtained by FNA or TCB cannot reliably confirm or exclude FIP as a sole diagnostic test $[117,118]$.

Besides its diagnostic use, IHC has also been applied to detect FCoV antigen in macrophages in unusual tissues or non-domestic felids. As such, FCoV antigen was detected in the skin of two cats with atypical skin lesions caused by FIP [120,121], in the penile tissue of a male cat [122], in different tissues obtained from a mountain lion [123] and in ocular tissues from a lion [124].

\subsection{Effusion}

Most often, immunofluorescence staining has been performed to detect $\mathrm{FCoV}$ antigen in effusions. For this, fluorescein-conjugated antibodies are used to detect FCoV antigen within the cytoplasm of macrophages [125]. In earlier studies, this test was reported to have an excellent specificity of $100 \%$. Therefore, it was believed that a positive result would in all cases allow a definitive diagnosis of FIP $[16,78,125,126]$. However, more recent investigations also showed positive results 
of immunofluorescence or ICC in cats with effusions caused by other diseases than FIP. Possible explanations for false positive results include binding of the antibody to cellular structures within macrophages (non-specific staining) or systemic spread and subsequent detection of FECV in cats without FIP $[127,128]$.

Sensitivity of immunostaining in effusion is not absolute; thus, a negative test result cannot exclude FIP [16,78,125-127]. Low numbers of macrophages in effusion samples or competitive binding of FCoV antigen by circulating antibodies in the effusion are possible reasons for false negative results. One study demonstrated that all cats with false negative test results had anti-FCoV antibodies in serum or effusion [78]. Only one study reported a sensitivity of $100 \%$ for the detection of FCoV antigen in effusion by immunofluorescence staining [128]. In contrast to other studies, which examined effusion samples obtained both ante and post mortem [125-127], this study only included samples collected ante mortem [128]. Additionally, a monoclonal biotinylated antibody was used, whereas previous studies applied a polyclonal fluorescein-conjugated antiserum in their staining protocols $[16,125,126]$. Finally, samples were analyzed within 24 hours after collection [128] and longer intervals between sampling and analysis could result in decreasing sensitivities. A decreasing sensitivity could be observed with increasing time interval between sample collection and analysis, although FCoV antigen could still be detected for at least two days in samples stored at $4{ }^{\circ} \mathrm{C}$ or room temperature [128]. Table 6 shows all studies investigating the detection of $\mathrm{FCoV}$ antigen in effusion. Reference standard was either histopathology $[16,78,125,128]$ and/or IHC $[126,127]$. Control groups consisted of cats with clinical signs consistent with FIP but a definitive diagnosis of another disease [16,78,125-128].

Table 6. Sensitivity and specificity from different studies evaluating immunostaining for the detection of feline coronavirus (FCoV) antigen in effusion samples. Feline infectious peritonitis (FIP) was confirmed either by histopathology alone or in combination with immunohistochemistry (IHC) of tissue samples. Control groups consisted of cats with diseases other than FIP with clinical signs consistent with FIP.

\begin{tabular}{llllllll}
\hline Study & $\begin{array}{l}\text { Sample } \\
\text { Material }\end{array}$ & $\begin{array}{l}\text { Number of } \\
\text { Samples }\end{array}$ & Assay & Sensitivity & Specificity & $\begin{array}{l}\text { Reference } \\
\text { Standard for FIP }\end{array}$ & $\begin{array}{l}\text { Control } \\
\text { Cats }\end{array}$ \\
\hline$[125]$ & $\begin{array}{l}\text { Ascites or } \\
\text { pleural } \\
\text { effusion }\end{array}$ & $\begin{array}{l}\text { FIP }(n=21) \\
\text { Controls } \\
(n=11)\end{array}$ & IFA & $95 \%$ & $100 \%$ & $\begin{array}{l}\text { Histopathology } \\
\text { Diseases } \\
\text { other than } \\
\text { FIP }\end{array}$ \\
\hline [78] & $\begin{array}{l}\text { Ascites or } \\
\text { pleural } \\
\text { effusion }\end{array}$ & $\begin{array}{l}\text { FIP }(n=49) \\
\text { Controls } \\
(n=50)\end{array}$ & IFA & $69 \%$ & $100 \%$ & Histopathology & $\begin{array}{l}\text { Diseases } \\
\text { other than }\end{array}$ \\
\hline FIP
\end{tabular}

ICC = immunocytochemistry; IFA = immunofluorescence.

\subsection{CSF}

It is also possible to detect FCoV antigen in the CSF of cats with FIP (with and without neurological signs) $[129,130]$. The only prospective study to date reported a sensitivity of $85 \%$ and a specificity of $83 \%$ for the immunocytochemical demonstration of FCoV antigen in macrophages in the CSF of 
cats with and without neurological signs (Table 7). In this study, IHC was the reference standard for the diagnosis of FIP; control cats had clinical signs typical for FIP, but other diseases were diagnosed histopathologically and IHC was negative in all cats. If only cats with neurological signs were evaluated, sensitivity surprisingly decreased to $78 \%$, whereas specificity slightly increased to $88 \%$. If only cats without neurological signs were evaluated, sensitivity was $91 \%$ and specificity only $50 \%$ [130].

Table 7. Sensitivity and specificity from a study evaluating immunostaining for the detection of feline coronavirus (FCoV) antigen in cerebrospinal fluid (CSF) samples. Feline infectious peritonitis (FIP) was confirmed by histopathology and immunohistochemistry (IHC) of tissue samples. The control group consisted of cats with diseases other than FIP with clinical signs (neurological or non-neurological) consistent with FIP.

\begin{tabular}{lllllll}
\hline Study & Number of Samples & Assay & Sensitivity & Specificity & $\begin{array}{l}\text { Reference Standard } \\
\text { for FIP }\end{array}$ & $\begin{array}{l}\text { Control } \\
\text { Cats }\end{array}$ \\
\hline$[130]$ & $\begin{array}{l}\text { FIP }(n=20) \\
\text { Controls }(n=18)\end{array}$ & ICC & $85 \%$ & $83 \%$ & Histopathology/IHC & $\begin{array}{l}\text { Diseases } \\
\text { other than } \\
\text { FIP }\end{array}$ \\
\hline$[130]$ & $\begin{array}{l}\text { FIP with neurological } \\
\text { signs }(n=9) \\
\text { Controls with } \\
\text { neurological signs }(n=16)\end{array}$ & ICC & $78 \%$ & $88 \%$ & Histopathology/IHC & $\begin{array}{l}\text { Diseases } \\
\text { other than } \\
\text { FIP }\end{array}$ \\
\hline$[130]$ & $\begin{array}{l}\text { FIP without neurological } \\
\text { signs }(n=11) \\
\text { Controls without } \\
\text { neurological signs }(n=2)\end{array}$ & ICC & $91 \%$ & $50 \%$ & Histopathology/IHC & $\begin{array}{l}\text { Diseases } \\
\text { other than } \\
\text { FIP }\end{array}$ \\
\hline
\end{tabular}

ICC = immunocytochemistry.

\subsection{Aqueous Humor}

In cats without FIP that do not present with effusion, uveitis is common and ocular signs (with or without involvement of the central nervous system) can be noticed in $60 \%$ of the affected cats $[12,131]$. Secondary to the inflammation of ocular structures and breakdown of the blood-ocular barrier, FCoV-bearing macrophages are present in the eye and FCoV antigen can be detected immunocytochemically within macrophages in the aqueous humor $[47,132]$. The results of the only prospective study that evaluated ICC in aqueous humor in cats with immunohistochemically confirmed FIP and control cats with similar clinical signs but histopathologically diagnosed other diseases are depicted in Table 8 [132]. The technique only has a moderate sensitivity and specificity for the diagnosis of FIP, and therefore, it cannot be used as a single confirming diagnostic test.

Table 8. Sensitivity and specificity from a study evaluating immunostaining for the detection of feline coronavirus (FCoV) antigen in aqueous humor samples. Feline infectious peritonitis (FIP) was confirmed by histopathology and immunohistochemistry (IHC) of tissue samples. The control group consisted of cats with diseases other than FIP with clinical signs (with or without uveitis) consistent with FIP.

\begin{tabular}{lllllll}
\hline Study & $\begin{array}{l}\text { Number of } \\
\text { Samples }\end{array}$ & Assay & Sensitivity & Specificity & $\begin{array}{l}\text { Reference Standard } \\
\text { for FIP }\end{array}$ & Control Cats \\
\hline$[132]$ & $\begin{array}{l}\text { FIP }(n=26) \\
\text { Controls }(n=12)\end{array}$ & ICC & $64 \%$ & $82 \%$ & Histopathology/IHC & $\begin{array}{l}\text { Diseases other } \\
\text { than FIP }\end{array}$ \\
\hline
\end{tabular}

ICC = immunocytochemistry.

\section{Detection of FCoV RNA by Reverse Transcriptase Polymerase Chain Reaction (RT-PCR)}

Since its first application for the detection of FCoV [133], RT-PCR is frequently used to amplify FCoV RNA in different materials and to diagnose FIP. According to the long-existing hypothesis that only FIPV but not FECV is able to spread systemically, it was initially believed that detection of FCoV 
RNA via RT-PCR in blood, effusion or any other body fluid or tissue except for the gastrointestinal tract indicates presence of the virulent pathotype FIPV [6,101,104,134]. This hypothesis has, however, been refuted by several studies (Tables 5-9) and it is important to keep in mind that FCoV RNA can also be amplified outside of the gastrointestinal tract in cats without FIP. Nevertheless, it is well known that cats with FIP exhibit much higher viral loads than healthy FECV-infected cats [54,135-137]. Therefore, an ideal RT-PCR assay should be able to quantify the viral load in order to facilitate diagnosis. Not only are tissue samples from cats with FIP more likely to be FCoV-positive, but also viral loads are significantly higher in cats with FIP compared to healthy FECV-infected cats $[135,137]$. As an example, in a study analyzing a large number of tissue and fluid samples, $90 \%$ of the tissue samples and $78 \%$ of the fluid samples from cats with FIP were positive, whereas only $8 \%$ of the tissue samples and $2 \%$ of the fluid samples from control cats were positive for FCoV RNA. Additionally, relative FCoV copy number (a Ct value of 40 in RT-PCR was assigned to a relative copy number of 1 , and a relative copy number was then calculated for each RT-PCR-positive sample using the following equation: $1.96^{(40-\mathrm{Ct} \text { value })}$ ) was significantly higher in tissue samples from cats with FIP than from FCoV-infected cats with other diseases or healthy FCoV-infected cats (median $8.3 \times 10^{3}$ vs. median 25) [135]. Thus, a positive RT-PCR result with a high viral load is at least very suggestive for FIP [138].

\subsection{Tissue}

In cats with FIP, large quantities of FCoV RNA can only be found in tissues with inflammatory changes. Tissues which are not involved in the disease process contain only small amounts or no viral RNA at all. Among the organs with highest viral loads are the omentum, mesenteric lymph nodes and spleen, so these tissues are most useful for analysis by RT-PCR. The kidneys, liver, lung, myocardium and popliteal lymph nodes, in contrast, contain little or no viral RNA [57]. Studies using RT-PCR to target FCoV RNA in tissues are summarized in Table 9. However, in veterinary practice, RT-PCR is rarely applied to tissue samples to diagnose FIP, as this would usually require invasive tissue sample collection via laparotomy or laparoscopy or has to be done post mortem. Therefore, the studies cited here were mainly performed for research purposes and did not have the aim of evaluating RT-PCR in tissue samples as a diagnostic test for FIP.

When an early study applied RT-PCR to tissue samples (liver, kidney and/or spleen), FCoV RNA was identified in $88 \%$ cats with clinically suspected FIP; $100 \%$ of experimentally infected cats tested positive for FCoV by RT-PCR. However, FCoV RNA was also detected in the tissues from $61 \%$ of cats without FIP [133], indicating that the detection of FCoV RNA in tissue is not specific for FIP. Especially in hemolymphatic tissues (spleen, mesenteric lymph nodes, bone marrow), FCoV RNA could be detected in all cats with FIP but also in $85 \%$ of clinically healthy FECV-infected cats. In cats with FIP, real-time RT-PCR was positive in the spleen in $60 \%$ of cases, in mesenteric lymph nodes in $87 \%$ and in the bone marrow in $67 \%$ of cases. In healthy FECV-infected cats, FCoV RNA was found in the spleen in $38 \%$, in mesenteric lymph nodes in $33 \%$ and in the bone marrow in $46 \%$ of cases [107]. As stated before, however, cats with FIP usually exhibit higher viral copy numbers in tissues than healthy FECV-infected cats $[107,135,137]$.

In order to develop a RT-PCR assay which is more specific for FIP, one study evaluated a real-time RT-PCR detecting messenger RNA (mRNA) (and thus, replicating virus). It was hypothesized that this RT-PCR would only detect FIPV from cats with FIP but not FECV from healthy FCoV-infected cats. Indeed, in this study, tissues from healthy FECV-infected cats tested negative for FCoV mRNA in all cases [139], whereas FCoV mRNA was found in the tissues of $71 \%$ of cats with immunohistochemically confirmed FIP. Organs with the highest frequency of harboring FCoV mRNA in these cats were the mesenteric lymph nodes $(100 \%)$, spleen $(88 \%)$, lung $(86 \%)$, liver $(75 \%)$, bronchial lymph nodes $(67 \%)$, kidneys $(63 \%)$ and intestine $(60 \%)$. 
Table 9. Sensitivity and specificity from different studies using reverse transcriptase polymerase chain reaction (RT-PCR) for the detection of feline coronavirus (FCoV) RNA in tissues from cats with feline infectious peritonitis (FIP) or control cats. FIP was confirmed by various methods and control groups either consisted of healthy cats or cats with diseases other than FIP (with or without clinical signs consistent with FIP).

\begin{tabular}{|c|c|c|c|c|c|c|c|}
\hline Study & Sample Material & $\begin{array}{l}\text { Number of } \\
\text { Samples }\end{array}$ & $\begin{array}{l}\text { RT-PCR } \\
\text { Assay }\end{array}$ & Sensitivity & Specificity & $\begin{array}{l}\text { Reference } \\
\text { Standard for FIP }\end{array}$ & $\begin{array}{l}\text { Control } \\
\text { Cats }\end{array}$ \\
\hline [133] & $\begin{array}{l}\text { Liver, kidney, } \\
\text { spleen }\end{array}$ & $\begin{array}{l}\mathrm{FIP}(n=8) \\
\text { Controls } \\
(n=84)\end{array}$ & RT-PCR & $88 \%$ & $39 \%$ & Histopathology & $\begin{array}{l}\text { Diseases } \\
\text { other than } \\
\text { FIP }\end{array}$ \\
\hline [133] & $\begin{array}{l}\text { Liver, kidney, } \\
\text { spleen }\end{array}$ & $\begin{array}{l}\text { Experimentally } \\
\text { induced FIP } \\
(n=13)\end{array}$ & RT-PCR & $100 \%$ & n. d. & $\begin{array}{l}\text { Experimen-tal } \\
\text { infection }\end{array}$ & None \\
\hline [107] & $\begin{array}{l}\text { Hemolymphatic } \\
\text { tissue }\end{array}$ & $\begin{array}{l}\text { FIP }(n=15) \\
\text { Controls } \\
(n=13)\end{array}$ & $\begin{array}{l}\text { Real-time } \\
\text { RT-PCR }\end{array}$ & $60-87 \%$ & $54-67 \%$ & Histopathology/IHC & Healthy \\
\hline [15] & $\begin{array}{l}\text { Mesenteric lymph } \\
\text { nodes, spleen, small } \\
\text { intestine, lung }\end{array}$ & $\begin{array}{l}\text { FIP }(n=11) \\
\text { Controls }(n=8)\end{array}$ & RT-nPCR & $91 \%$ & $50 \%$ & Histopathology/IHC & $\begin{array}{l}\text { Diseases } \\
\text { other than } \\
\text { FIP }\end{array}$ \\
\hline [139] & Various tissues & $\begin{array}{l}\text { FIP }(n=32) \\
\text { Controls }(n=9)\end{array}$ & $\begin{array}{l}\text { Real-time } \\
\text { RT-PCR } \\
\text { for mRNA }\end{array}$ & $60-100 \%$ & $100 \%$ & Histopathology/IHC & Healthy \\
\hline [137] & Various tissues & $\begin{array}{l}\text { FIP }(n=45) \\
\text { Controls } \\
(n=41)\end{array}$ & $\begin{array}{l}\text { Real-time } \\
\text { RT-PCR }\end{array}$ & $96 \%$ & $78 \%$ & Histopathology/IHC & $\begin{array}{l}\text { Diseases } \\
\text { other than } \\
\text { FIP }\end{array}$ \\
\hline [140] & $\begin{array}{l}\text { FNA of various } \\
\text { tissues }\end{array}$ & $\operatorname{FIP}(n=11)$ & RT-PCR & $100 \%$ & n. d. & Histopathology & None \\
\hline [141] & Various tissues & $\mathrm{FIP}(n=20)$ & $\begin{array}{l}\text { Real-time } \\
\text { RT-PCR }\end{array}$ & $65-95 \%$ & n. d. & Histopathology/IHC & None \\
\hline
\end{tabular}

FNA = fine-needle aspirates; IHC = immunohistochemistry; mRNA = messenger RNA; . d. = not determined; RT-nPCR = nested RT-PCR; RT-qPCR = quantitative RT-PCR.

Recent studies evaluated the use of a quantitative RT-PCR (RT-qPCR) to detect FCoV RNA in FNA samples of the mesenteric lymph nodes and other abnormal tissues of clinical cases $[119,140]$ and hypothesized that this technique would be a useful tool to diagnose FIP for veterinary practitioners, especially in cats without effusion. The first study included control cats that were either FCoV antibody-negative or antibody-positive but without signs indicative of FIP or with a confirmation of another cause of illness/death. Additionally, cats with non-effusive FIP, that was confirmed either by histopathology or a diagnostic algorithm, were included. In all of the cats, the mesenteric lymph nodes were sampled by minimally invasive ultrasound-guided FNA and examined by RT-qPCR. It was found that the detection of FCoV RNA in mesenteric lymph node FNA can be a sensitive and specific method to diagnose FIP (even when analyzed after shipping without any preservatives), although FCoV RNA was also detected in the mesenteric lymph nodes of a small proportion of cats without FIP, and therefore, was not completely specific for FIP [119]. The second study retrospectively included eleven cats with FIP without effusions and successfully amplified FCoV RNA from FNA samples of various organs in all of the cats. Since no control group was included in that study, specificity could not be evaluated [140]. The same finding was made in a study in which different samples (FNA or 
incisional biopsies (IB)) were obtained from different tissues (mesenteric and popliteal lymph nodes, liver, kidney, spleen, omentum) of 20 cats with immunohistochemically confirmed FIP in order to determine the prevalence of FCoV RNA in different tissues and to potentially evaluate the diagnostic performance of RT-PCR on those tissue samples for diagnosing FIP. Sensitivity was high in most tissues except for the popliteal lymph nodes and sensitivities did not greatly differ whether FNA or IB were used. Since no control group was included, specificity could not be determined [141].

\subsection{Blood}

Based on the erroneous assumption that only FIPV but not FECV is able to infect monocytes/macrophages and disseminate systemically, it was thought that the detection of FCoV RNA in blood was proof of an infection with FIPV, and thus, FIP. Therefore, RT-PCR was initially developed using primers for the highly conserved 3'-untranslated region (3'-UTR) of the FCoV genome in order to detect all known FCoV isolates. As a result, the RT-PCR could neither differentiate between FECV and FIPV, nor could it distinguish FCoV from CCV or TGEV. Nevertheless, as stated before, it was assumed that only FIPV would be detectable in blood. However, over the years, it has been shown that FCoV RNA could also be detected in the blood of asymptomatic cats and cats with diseases other than FIP $[143,144]$. Several studies evaluating the use of RT-PCR in serum, plasma or whole blood confirmed this finding of possible FCoV viremia in cats without FIP [16,80,106,145-147]. Additionally, a recent study demonstrated that FCoV viremia does not even predict the development of FIP, as none of the healthy cats that tested positive for genomic or replicating FCoV developed FIP or clinical illness within six months of testing [147].

All of the studies using RT-PCR on blood samples are summarized in Table 10. If different blood fractions were examined, sensitivity and specificity are presented as a range. Most studies used histopathology as reference standard [16,80,106,143,145,148,149]; one study also used the detection of FCoV antigen in macrophages in effusion [149]. Some studies had the limitation of including cats in which FIP was suspected clinically, but the diagnosis was not confirmed $[148,150,151]$. The control groups either consisted of healthy cats $[106,143,145,147,148,150,151]$ and/or of cats with other diseases than FIP, sometimes showing clinical signs consistent with FIP $[16,80,143,145,148,149]$.

One additional study worth mentioning is not shown in Table 10. This study included 63 serum samples from 62 cats with abdominal clinical signs. Since no definitive diagnosis was established in these cats, sensitivity and specificity could not be determined, and therefore, the study was not mentioned in Table 10. Nevertheless, it is worth noting that in this study, 18 cats had a positive result in a nested RT-PCR (RT-nPCR) assay. One of these cats survived for almost three years after examination; four additional cats lived for at least 70 months. Since median survival time for cats with FIP is very short (unless new antiviral drugs are applied) [152], it is likely that these cats did not have FIP and that the RT-nPCR was false positive [146].

Since FCoV viremia can be detected by RT-PCR in up to $80-90 \%$ of FECV-infected cats without FIP [106], detection of FCoV RNA in blood is not specific for FIP and RT-PCR in blood samples should not be used to confirm a diagnosis of FIP. Additionally, FCoV viral load is low in any blood fraction in experimental FIP [57] and this is most likely also the case in natural infection, leading to a rather low sensitivity of RT-PCR in blood. RT-PCR had better sensitivity when peripheral blood mononuclear cells (PBMC) were used compared to serum [149]; however, other studies came to differing results regarding sensitivity in the different blood fractions and most studies are not well comparable $[80,106,141,143]$. Sensitivity was poor in most of the studies; therefore, due to a rather low virus load and resulting low sensitivities, blood samples are not recommended for analysis by RT-PCR.

Although FECV can infect monocytes and macrophages, it is not capable of efficiently replicating within them $[101,147,153,154]$. In an attempt to increase specificity of RNA detection in blood, a RT-PCR specifically amplifying FCoV mRNA has been developed in order to detect only actively replicating virus in blood. In an initial study, this RT-PCR assay really did not detect FCoV mRNA in any of the control cats with clinical signs indicative of FIP but other confirmed diseases, whereas FCoV mRNA 
was found in $93 \%$ of cats with histopathologically confirmed FIP [148]. Nevertheless, subsequent studies also identified FCoV mRNA, and thus, replicating FCoV in $0.5-52 \%$ blood samples from healthy cats $[147,148,150,151]$ and the detection of replicating virus did not predispose to the development of FIP [147]. Therefore, this special RT-PCR assay also is not adequately specific for FIP.

Table 10. Sensitivity and specificity from different studies using reverse transcriptase polymerase chain reaction (RT-PCR) for the detection of feline coronavirus (FCoV) RNA in blood from cats with feline infectious peritonitis (FIP) or control cats. FIP was confirmed by various methods and control groups either consisted of healthy cats or cats with diseases other than FIP (with or without clinical signs consistent with FIP).

\begin{tabular}{|c|c|c|c|c|c|c|c|}
\hline Study & Sample Material & $\begin{array}{l}\text { Number of } \\
\text { Samples }\end{array}$ & $\begin{array}{l}\text { RT-PCR } \\
\text { Assay }\end{array}$ & Sensitivity & Specificity & $\begin{array}{l}\text { Reference } \\
\text { Standard for FIP }\end{array}$ & Control Cats \\
\hline [143] & Serum, plasma & $\begin{array}{l}\text { FIP }(n=17) \\
\text { Controls }(n=15)\end{array}$ & RT-nPCR & $56-75 \%$ & $75-88 \%$ & Histopathology & $\begin{array}{l}\text { Healthy or } \\
\text { diseases other } \\
\text { than FIP }\end{array}$ \\
\hline [145] & Plasma & $\begin{array}{l}\text { FIP }(n=42) \\
\text { Controls } \\
(n=141)\end{array}$ & RT-nPCR & $71 \%$ & $89 \%$ & Histopathology & $\begin{array}{l}\text { Healthy or } \\
\text { diseases other } \\
\text { than FIP }\end{array}$ \\
\hline [106] & $\begin{array}{l}\text { Serum, plasma, } \\
\text { whole blood }\end{array}$ & $\begin{array}{l}\text { FIP }(n=47) \\
\text { Controls }(n=69)\end{array}$ & RT-snPCR & $67-87 \%$ & $10-20 \%$ & Histopathology & Healthy \\
\hline [80] & $\begin{array}{l}\text { Serum, plasma, } \\
\text { whole blood }\end{array}$ & $\begin{array}{l}\text { FIP }(n=6) \\
\text { Controls }(n=5)\end{array}$ & RT-nPCR & $20-75 \%$ & $100 \%$ & Histopathology & $\begin{array}{l}\text { Diseases other } \\
\text { than FIP }\end{array}$ \\
\hline [16] & Serum & $\begin{array}{l}\text { FIP }(n=17) \\
\text { Controls }(n=8)\end{array}$ & RT-nPCR & $53 \%$ & $88 \%$ & Histopathology & $\begin{array}{l}\text { Diseases other } \\
\text { than FIP }\end{array}$ \\
\hline [148] & PBMC & $\begin{array}{l}\text { FIP }(n=81) \\
\text { Controls }(n=17)\end{array}$ & $\begin{array}{l}\text { RT-PCR } \\
\text { for mRNA }\end{array}$ & $93 \%$ & $100 \%$ & Histopathology & $\begin{array}{l}\text { Healthy or } \\
\text { diseases other } \\
\text { than FIP }\end{array}$ \\
\hline [148] & PBMC & $\begin{array}{l}\text { FIP }(n=651) \\
\text { Controls } \\
(n=424)\end{array}$ & $\begin{array}{l}\text { RT-PCR } \\
\text { for mRNA }\end{array}$ & $46 \%$ & $95 \%$ & $\begin{array}{l}\text { Histopathology or } \\
\text { only clinical } \\
\text { suspicion }\end{array}$ & $\begin{array}{l}\text { Healthy or } \\
\text { diseases other } \\
\text { than FIP }\end{array}$ \\
\hline [151] & Whole blood & $\begin{array}{l}\text { FIP }(n=1) \\
\text { Controls }(n=25)\end{array}$ & $\begin{array}{l}\text { RT-PCR } \\
\text { for mRNA }\end{array}$ & $100 \%$ & $48 \%$ & Clinical suspicion & Healthy \\
\hline [150] & Whole blood & $\begin{array}{l}\text { FIP }(n=10) \\
\text { Controls }(n=40)\end{array}$ & RT-PCR & $100 \%$ & $33 \%$ & Clinical suspicion & Healthy \\
\hline [150] & Whole blood & $\begin{array}{l}\text { FIP }(n=10) \\
\text { Controls }(n=40)\end{array}$ & $\begin{array}{l}\text { RT-PCR } \\
\text { for mRNA }\end{array}$ & $100 \%$ & $85 \%$ & Clinical suspicion & Healthy \\
\hline [139] & WBC & $\operatorname{FIP}(n=2)$ & $\begin{array}{l}\text { Real-time } \\
\text { RT-PCR } \\
\text { for mRNA }\end{array}$ & $100 \%$ & n. d. & Histopathology/IHC & Healthy \\
\hline [149] & Serum, PBMC & $\begin{array}{l}\text { FIP }(n=43) \\
\text { Controls }(n=49)\end{array}$ & $\begin{array}{l}\text { Real-time } \\
\text { RT-PCR }\end{array}$ & $15-29 \%$ & $100 \%$ & $\begin{array}{l}\text { Histopathology or } \\
\text { detection of FCoV } \\
\text { antigen in effusion }\end{array}$ & $\begin{array}{l}\text { Diseases other } \\
\text { than FIP }\end{array}$ \\
\hline [155] & Whole blood & $\begin{array}{l}\text { FCoV-positive } \\
(n=4) \\
\text { FCoV-negative } \\
(n=5)\end{array}$ & RT-LAMP & $25-50 \%$ & $100 \%$ & RT-nPCR & $\begin{array}{l}\text { Diseases other } \\
\text { than FIP }\end{array}$ \\
\hline [156] & Serum/plasma & $\begin{array}{l}\text { FIP }(n=32) \\
\text { Controls }(n=21)\end{array}$ & RT-nPCR & $9 \%$ & $100 \%$ & $\begin{array}{l}\text { Histopathology, } \\
\text { IHC or detection of } \\
\text { FCoV antigen in } \\
\text { effusion }\end{array}$ & $\begin{array}{l}\text { Diseases other } \\
\text { than FIP }\end{array}$ \\
\hline [157] & Serum/plasma & $\begin{array}{l}\text { FIP }(n=14) \\
\text { Controls }(n=3)\end{array}$ & $\begin{array}{l}\text { Real-time } \\
\text { RT-PCR }\end{array}$ & $14 \%$ & $100 \%$ & $\begin{array}{l}\text { Histopathology or } \\
\text { IHC }\end{array}$ & $\begin{array}{l}\text { Diseases other } \\
\text { than FIP }\end{array}$ \\
\hline [15] & Whole blood & $\begin{array}{l}\text { FIP }(n=8) \\
\text { Controls }(n=8)\end{array}$ & RT-nPCR & $75 \%$ & $100 \%$ & Histopathology/IHC & $\begin{array}{l}\text { Diseases other } \\
\text { than FIP }\end{array}$ \\
\hline [147] & Buffy coat & Controls $(n=205)$ & RT-qPCR & n. d. & $96 \%$ & None & Healthy \\
\hline [147] & Buffy coat & Controls $(n=205)$ & $\begin{array}{l}\text { RT-qPCR } \\
\text { for mRNA }\end{array}$ & n. d. & $99.5 \%$ & None & Healthy \\
\hline [141] & $\begin{array}{l}\text { Buffy coat, serum } \\
\text { or whole blood }\end{array}$ & $\operatorname{FIP}(n=20)$ & $\begin{array}{l}\text { Real-time } \\
\text { RT-PCR }\end{array}$ & $36-77 \%$ & n. d. & Histopathology/IHC & None \\
\hline
\end{tabular}

IHC = immunohistochemistry; mRNA = messenger RNA; $\mathrm{n} . \mathrm{d}$. = not determined; PBMC = peripheral blood mononuclear cells; RT-LAMP = reverse transcriptase loop-mediated isothermal amplification; RT-nPCR = nested RT-PCR; RT-snPCR = semi-nested RT-PCR; RT-qPCR = quantitative RT-PCR; WBC = white blood cells. 
In general, however, cats with FIP exhibit higher viral loads and copy numbers than healthy FECV-infected cats $[107,137]$ and higher viral copy numbers are found in the feces of healthy FECV-infected cats when compared to their blood [147]. Therefore, an RT-PCR that allows simultaneous amplification and quantification of viral mRNA could potentially distinguish FECV (with low viral copy numbers) from FIPV (with high viral copy numbers). A real-time RT-PCR based on primer-probe energy transfer detecting and quantifying subgenomic FCoV mRNA showed a very good sensitivity and specificity in one study, but was so far only applied on very small numbers of samples and not used in the field [139]. Loop-mediated isothermal amplification (LAMP) is a new molecular method with the advantage of delivering rapid in-house test results. Reverse transcriptase LAMP (RT-LAMP) has been used to amplify FCoV RNA in blood, effusion, lymph nodes and feces of cats with suspected FIP in a recent study, in which RT-nPCR was used as reference standard. Specificity of RT-LAMP was $100 \%$ in all materials; sensitivity, however, was only low to moderate [155].

\subsection{Effusion}

In cats with FIP that have effusion, virus load is much higher in the effusion than in blood [57]. Sensitivities and specificities of RT-PCR assays for the diagnosis of FIP in effusion are listed in Table 11. As shown, sample numbers are relatively low in some and especially in the older studies. Most studies used histopathology as reference standard $[16,22,149,158,159]$; in some studies, the detection of FCoV antigen in effusion $[149,159]$ or tissue $[159,160]$ or laboratory fluid analysis $[158]$ was the reference standard. One study included 27 cats with a suspicion of FIP, of which only 13 had histopathologic confirmation of the disease and 8/13 cats had effusion [80]. Another study examined 61 effusion samples from cats with suspected FIP based on effusion feature criteria established by the European Advisory Board on Cat Diseases in 2009 [88]. The diagnosis was, however, not confirmed by reference standard methods in any of the cats [89]. The control groups consisted of cats with a clinical suspicion of FIP but different diagnoses [16,149,158-160].

One study examined a large number of effusion samples from 854 cats with clinically suspected FIP; the disease was, however, not confirmed. It could also not be determined whether cats with negative RT-PCR results had diseases other than FIP. Therefore, sensitivity and specificity could not be calculated, but FCoV RNA was detected in the effusion of 377/854 cats (44\%) [161]. In another study, plasma and/or ascites from 42 cats with histopathologically confirmed FIP and 141 controls (healthy or with FIP-typical clinical signs but other diseases) were examined by RT-nPCR. FCoV RNA was detected in the plasma of $70 \%$ of cats with FIP. Five additional cats that tested negative in plasma had a positive RT-nPCR result in effusion. However, it was not stated how many effusion samples were analyzed in total [145]; thus, the study was not included in Table 11.

Although specificity of RT-PCR in effusion was high in many studies and a positive RT-PCR result can add to a suspicion of FIP, it has to be kept in mind that RT-PCR already detects small amounts of viral RNA, which can potentially leak from blood into effusion in the face of inflammation (even without FIP) in cats with circulating FECV [110]. Especially in recent studies, FCoV RNA could also be detected in the effusion of cats without FIP $[15,135,157,159]$.

\subsection{CSF}

All studies evaluating RT-PCR for the detection of FCoV RNA in CSF have reported specificities of $100 \%$, meaning that FCoV RNA could only be detected in the CSF of cats with FIP (with and without neurological signs) but not control cats (Table 12). Reference standards used in these studies was either histopathology $[45,162]$ and/or the detection of FCoV antigen in effusion [162] or tissue [135]. The control groups consisted of cats with neurologic diseases only [45] or also included cats with non-neurologic diseases but clinical signs consistent with FIP [135,162]. 
Table 11. Sensitivity and specificity from different studies using reverse transcriptase polymerase chain reaction (RT-PCR) for the detection of feline coronavirus (FCoV) RNA in effusion from cats with feline infectious peritonitis (FIP) or control cats. FIP was confirmed by various methods and control groups either consisted of healthy cats or cats with diseases other than FIP (with or without clinical signs consistent with FIP).

\begin{tabular}{|c|c|c|c|c|c|c|c|}
\hline Study & $\begin{array}{l}\text { Sample } \\
\text { Material }\end{array}$ & $\begin{array}{l}\text { Number of } \\
\text { Samples }\end{array}$ & $\begin{array}{l}\text { RT-PCR } \\
\text { Assay }\end{array}$ & Sensitivity & Specificity & $\begin{array}{l}\text { Reference } \\
\text { Standard for FIP }\end{array}$ & Control Cats \\
\hline [143] & Ascites & $\begin{array}{l}\operatorname{FIP}(n=5) \\
\text { Controls }(n=1)\end{array}$ & RT-nPCR & $100 \%$ & $100 \%$ & Histopathology & $\begin{array}{l}\text { Healthy or } \\
\text { diseases other } \\
\text { than FIP }\end{array}$ \\
\hline [158] & $\begin{array}{l}\text { Ascites or } \\
\text { pleural } \\
\text { effusion }\end{array}$ & $\begin{array}{l}\text { FIP }(n=12) \\
\text { Controls } \\
(n=11)\end{array}$ & RT-nPCR & $91 \%$ & $94 \%$ & $\begin{array}{l}\text { Histopathology or } \\
\text { laboratory fluid } \\
\text { analysis }\end{array}$ & $\begin{array}{l}\text { Diseases other } \\
\text { than FIP }\end{array}$ \\
\hline [80] & $\begin{array}{l}\text { Ascites or } \\
\text { pleural } \\
\text { effusion }\end{array}$ & $\begin{array}{l}\text { FIP }(n=5) \\
\text { Controls }(n=3)\end{array}$ & RT-nPCR & $100 \%$ & $100 \%$ & $\begin{array}{l}\text { Histopathology } \\
\text { (some cats) }\end{array}$ & $\begin{array}{l}\text { Diseases other } \\
\text { than FIP }\end{array}$ \\
\hline [16] & $\begin{array}{l}\text { Ascites or } \\
\text { pleural } \\
\text { effusion }\end{array}$ & $\begin{array}{l}\text { FIP }(n=5) \\
\text { Controls }(n=1)\end{array}$ & RT-nPCR & $100 \%$ & $100 \%$ & Histopathology & $\begin{array}{l}\text { Diseases other } \\
\text { than FIP }\end{array}$ \\
\hline [22] & $\begin{array}{l}\text { Ascites or } \\
\text { pleural } \\
\text { effusion }\end{array}$ & FIP $(n=27)$ & RT-nPCR & $96 \%$ & n. d. & Histopathology & None \\
\hline [160] & $\begin{array}{l}\text { Ascites, } \\
\text { pleural or } \\
\text { pericardial } \\
\text { effusion }\end{array}$ & $\begin{array}{l}\text { FIP }(n=20) \\
\text { Controls } \\
(n=23)\end{array}$ & $\begin{array}{l}\text { Real-time } \\
\text { RT-PCR }\end{array}$ & $85 \%$ & $100 \%$ & Histopathology/IHC & $\begin{array}{l}\text { Diseases other } \\
\text { than FIP }\end{array}$ \\
\hline [149] & $\begin{array}{l}\text { Ascites or } \\
\text { pleural } \\
\text { effusion }\end{array}$ & $\begin{array}{l}\text { FIP }(n=36) \\
\text { Controls }(n=33)\end{array}$ & $\begin{array}{l}\text { Real-time } \\
\text { RT-PCR }\end{array}$ & $89 \%$ & $100 \%$ & $\begin{array}{l}\text { Histopathology or } \\
\text { detection of FCoV } \\
\text { antigen in effusion }\end{array}$ & $\begin{array}{l}\text { Diseases other } \\
\text { than FIP }\end{array}$ \\
\hline [155] & Effusion & $\begin{array}{l}\text { FCoV-positive } \\
(n=5) \\
\text { FCoV-negative } \\
(n=3)\end{array}$ & RT-LAMP & $40 \%$ & $100 \%$ & RT-nPCR & $\begin{array}{l}\text { Diseases other } \\
\text { than FIP }\end{array}$ \\
\hline [159] & $\begin{array}{l}\text { Ascites or } \\
\text { pleural } \\
\text { effusion }\end{array}$ & $\begin{array}{l}\text { FIP }(n=34) \\
\text { Controls }(n=37)\end{array}$ & RT-LAMP & $35-59 \%$ & $95-97 \%$ & $\begin{array}{l}\text { Histopathology or } \\
\text { detection of FCoV } \\
\text { antigen in effusion } \\
\text { or tissue }\end{array}$ & $\begin{array}{l}\text { Diseases other } \\
\text { than FIP }\end{array}$ \\
\hline [89] & $\begin{array}{l}\text { Ascites or } \\
\text { pleural } \\
\text { effusion }\end{array}$ & FIP $(n=61)$ & RT-qPCR & $85 \%$ & n. d. & $\begin{array}{l}\text { Combination of } \\
\text { tests (according to } \\
\text { ABCD guidelines) }\end{array}$ & None \\
\hline [135] & $\begin{array}{l}\text { Ascites, } \\
\text { pleural or } \\
\text { pericardial } \\
\text { effusion }\end{array}$ & $\begin{array}{l}\text { FIP }(n=35) \\
\text { Controls }(n=28)\end{array}$ & RT-qPCR & $91 \%$ & $96 \%$ & Histopathology/IHC & $\begin{array}{l}\text { Healthy or } \\
\text { diseases other } \\
\text { than FIP }\end{array}$ \\
\hline [156] & $\begin{array}{l}\text { Ascites, } \\
\text { pleural or } \\
\text { pericardial } \\
\text { effusion }\end{array}$ & $\begin{array}{l}\text { FIP }(n=50) \\
\text { Controls }(n=51)\end{array}$ & RT-nPCR & $72 \%$ & $100 \%$ & $\begin{array}{l}\text { Histopathology, } \\
\text { IHC or detection of } \\
\text { FCoV antigen in } \\
\text { effusion }\end{array}$ & $\begin{array}{l}\text { Diseases other } \\
\text { than FIP }\end{array}$ \\
\hline [157] & $\begin{array}{l}\text { Ascites or } \\
\text { pleural } \\
\text { effusion }\end{array}$ & $\begin{array}{l}\text { FIP }(n=35) \\
\text { Controls }(n=24)\end{array}$ & $\begin{array}{l}\text { Real-time } \\
\text { RT-PCR }\end{array}$ & $97 \%$ & $88 \%$ & $\begin{array}{l}\text { Histopathology } \\
\text { and/or IHC }\end{array}$ & $\begin{array}{l}\text { Diseases other } \\
\text { than FIP }\end{array}$ \\
\hline [15] & Effusion & $\begin{array}{l}\text { FIP }(n=10) \\
\text { Controls }(n=6)\end{array}$ & RT-nPCR & $100 \%$ & $83 \%$ & Histopathology/IHC & $\begin{array}{l}\text { Diseases other } \\
\text { than FIP }\end{array}$ \\
\hline [141] & Effusion & $\operatorname{FIP}(n=14)$ & $\begin{array}{l}\text { Real-time } \\
\text { RT-PCR }\end{array}$ & $86 \%$ & n. d. & Histopathology/IHC & None \\
\hline
\end{tabular}

$\mathrm{ABCD}=$ European Advisory Board on Cat Diseases; IHC = immunohistochemistry; $\mathrm{n} . \mathrm{d}$. = not determined; RT-LAMP = reverse transcriptase loop-mediated isothermal amplification; RT-nPCR = nested RT-PCR; RT-qPCR = quantitative RT-PCR. 
Table 12. Sensitivity and specificity from different studies using reverse transcriptase polymerase chain reaction (RT-PCR) for the detection of feline coronavirus (FCoV) RNA in cerebrospinal fluid (CSF) from cats with feline infectious peritonitis (FIP) or control cats. FIP was confirmed by histopathology or detection of FCoV antigen and control groups consisted of cats with diseases other than FIP (either only neurologic or also non-neurologic diseases with clinical signs consistent with FIP).

\begin{tabular}{|c|c|c|c|c|c|c|c|}
\hline Study & $\begin{array}{l}\text { Sample } \\
\text { Material }\end{array}$ & $\begin{array}{l}\text { Number of } \\
\text { Samples }\end{array}$ & $\begin{array}{l}\text { RT-PCR } \\
\text { Assay }\end{array}$ & Sensitivity & Specificity & $\begin{array}{l}\text { Reference } \\
\text { Standard for FIP }\end{array}$ & $\begin{array}{l}\text { Control } \\
\text { Cats }\end{array}$ \\
\hline [45] & CSF & $\begin{array}{l}\text { FIP }(n=24) \\
\text { Controls }(n=3)\end{array}$ & RT-PCR & $21 \%$ & $100 \%$ & Histopathology & $\begin{array}{l}\text { Neurologic } \\
\text { diseases } \\
\text { other than } \\
\text { FIP }\end{array}$ \\
\hline [45] & CSF & $\begin{array}{l}\text { FIP with } \\
\text { neurological } \\
\text { signs }(n=16) \\
\text { Controls with } \\
\text { neurological } \\
\text { signs }(n=3)\end{array}$ & RT-PCR & $31 \%$ & $100 \%$ & Histopathology & $\begin{array}{l}\text { Neurologic } \\
\text { diseases } \\
\text { other than } \\
\text { FIP }\end{array}$ \\
\hline [162] & CSF & $\begin{array}{l}\operatorname{FIP}(n=19) \\
\text { Controls }(n=15)\end{array}$ & $\begin{array}{l}\text { Real-time } \\
\text { RT-PCR }\end{array}$ & $42 \%$ & $100 \%$ & $\begin{array}{l}\text { Histopathology or } \\
\text { detection of FCoV } \\
\text { antigen in effusion }\end{array}$ & $\begin{array}{l}\text { Diseases } \\
\text { other than } \\
\text { FIP }\end{array}$ \\
\hline [162] & CSF & $\begin{array}{l}\text { FIP with } \\
\text { neurological } \\
\text { and/or ocular } \\
\text { signs }(n=7) \\
\text { Controls with } \\
\text { neurological } \\
\text { and/or ocular } \\
\text { signs }(n=3)\end{array}$ & $\begin{array}{l}\text { Real-time } \\
\text { RT-PCR }\end{array}$ & $86 \%$ & $100 \%$ & $\begin{array}{l}\text { Histopathology or } \\
\text { detection of FCoV } \\
\text { antigen in effusion }\end{array}$ & $\begin{array}{l}\text { Diseases } \\
\text { other than } \\
\text { FIP }\end{array}$ \\
\hline [135] & CSF & $\begin{array}{l}\text { FIP }(n=14) \\
\text { Controls }(n=19)\end{array}$ & RT-qPCR & $50 \%$ & $100 \%$ & Histopathology/IHC & $\begin{array}{l}\text { Healthy or } \\
\text { diseases } \\
\text { other than } \\
\text { FIP }\end{array}$ \\
\hline [141] & CSF & $\operatorname{FIP}(n=16)$ & $\begin{array}{l}\text { Real-time } \\
\text { RT-PCR }\end{array}$ & $63 \%$ & n. d. & Histopathology/IHC & None \\
\hline
\end{tabular}

IHC = immunohistochemistry; $n$. d. = not determined; RT-qPCR = quantitative RT-PCR.

Although the blood-brain barrier has not specifically been examined in cats with FIP yet, it can be assumed that it is impaired secondary to the inflammation caused by FIP [163]. In general, various infectious and inflammatory diseases of the central nervous system lead to the release of cytokines, adhesion molecules, metalloproteases and other mediators, which can damage tight junctions, basal membranes and cerebrovascular endothelium. This enables the leakage of cells and pathogens into the CSF across the blood-brain barrier [163]. Therefore, although false positive RT-PCR results have not been reported in CSF thus far, it seems theoretically possible that FECV could pass the blood-brain barrier in cats with neurologic diseases other than FIP, as it is also suspected for anti-FCoV antibodies [46]. One study detected a correlation between high anti-FCoV antibodies and positive RT-PCR in the CSF. In that study, FCoV RNA was found in only $15 \%$ of samples from cats with low, but in $100 \%$ of samples from cats with high CSF antibody titers. In contrast, FCoV RNA was not amplified in any of the antibody-negative cats. However, FIP was not confirmed in the cats in this study [90].

\subsection{Aqueous Humor}

Another type of sample material that can be examined for FCoV RNA by RT-PCR is the aqueous humor. To date, there have been very few studies that evaluated this sample material for analysis by RT-PCR in a small number of cats with FIP (Table 13). Additionally, a case report demonstrated positive RT-PCR in the aqueous humor of 3/10 cats with uveitis; however, there were no clear-defined FIP and control groups [131]. 
Table 13. Sensitivity and specificity from studies using reverse transcriptase polymerase chain reaction (RT-PCR) for the detection of feline coronavirus (FCoV) RNA in aqueous humor samples from cats with feline infectious peritonitis (FIP) or control cats. FIP was confirmed by immunohistochemistry (IHC) and control groups either consisted of cats with diseases other than FIP or cats euthanized due to behavioral conditions.

\begin{tabular}{llllllll}
\hline Study & $\begin{array}{l}\text { Sample } \\
\text { Material }\end{array}$ & $\begin{array}{l}\text { Number of } \\
\text { Samples }\end{array}$ & Assay & Sensitivity & Specificity & $\begin{array}{l}\text { Reference } \\
\text { Standard } \\
\text { for FIP }\end{array}$ & Control Cats \\
\hline$[135]$ & $\begin{array}{l}\text { Aqueous } \\
\text { humor }\end{array}$ & FIP $(n=2)$ & RT-qPCR & $50 \%$ & n. d. & IHC & $\begin{array}{l}\text { Healthy or } \\
\text { diseases other } \\
\text { than FIP }\end{array}$ \\
\hline$[141]$ & $\begin{array}{l}\text { Aqueous } \\
\text { humor }\end{array}$ & FIP $(n=20)$ & $\begin{array}{l}\text { Real-time } \\
\text { RT-PCR }\end{array}$ & $25 \%$ & n. d. & IHC & None \\
\hline$[164]$ & $\begin{array}{l}\text { Aqueous } \\
\text { humor }\end{array}$ & $\begin{array}{l}\text { FIP }(n=25) \\
\text { Controls }(n=11)\end{array}$ & $\begin{array}{l}\text { Real-time } \\
\text { RT-PCR }\end{array}$ & $40 \%$ & $100 \%$ & IHC & $\begin{array}{l}\text { Diseases other } \\
\text { than FIP }\end{array}$ \\
\hline
\end{tabular}

n. d. = not determined; RT-qPCR = quantitative RT-PCR.

\section{Detection of FCoV Mutations}

FCoV replication, like replication of all RNA viruses, is prone to error [165]. Multiple individual mutations occur during each cycle of viral replication [12,58,166,167]. It is hypothesized that specific mutations or a combination of mutations then lead to the development of the virulent pathotype FIPV and trigger the tropism switch from enterocytes to macrophages as a key event in FIP pathogenesis $[4,153,168]$.

Several different $\mathrm{FCoV}$ genes have been analyzed and suggested to harbor the mutation responsible for the FCoV pathotype switch. Open reading frame (ORF) 3abc, which is coding for the accessory proteins $3 \mathrm{a}, 3 \mathrm{~b}$ and $3 \mathrm{c}$, has been sequenced and compared in FCoV from cats with FIP and healthy cats and differences were detected. For instance, it was found that FIPV from tissue or effusion of cats with FIP contained a truncated protein $3 c$, whereas FECV from feces of healthy cats most often contained an intact protein $3 c[108,167,169-173]$. The $3 a$ and $3 b$ genes could play a role in FIP pathogenesis as well [174-176]. ORF 7ab, coding for accessory proteins $7 \mathrm{a}$ and $7 \mathrm{~b}$, has also been subject of studies looking into FIP pathogenesis, but somewhat contradictory results were found [77,153,169,170,176-181]. The FCoV spike (S) protein is responsible for viral cell entry. It includes a subunit for receptor binding (S1) and a subunit mediating membrane fusion (S2) [182-184]. Therefore, mutations in the FCoV S gene, more specific mutations in the S2 region and corresponding amino acid substitutions in the S protein, have been suggested to be responsible for the change of viral cell tropism [153,170,185-187]. As a result, only FIPV but not FECV are capable of efficient and sustained replication in macrophages, producing large amounts of viral particles and spreading the infection to adjacent cells [153,154]. Therefore, the $S$ gene is of particular interest with regard to determining which mutations are responsible for the transition from FECV to FIPV. Recently, commercial diagnostic testing was introduced for FCoV S gene mutations.

When the $\mathrm{S}$ genes of a large number of FCoV derived from the feces of healthy cats and from tissues or ascites of cats with FIP were sequenced, two single nucleotide polymorphisms (SNP) were found that only were present in the FCoV from cats with FIP but not in the FCoV from healthy cats. These SNP were found at nucleotide position 23531 and 23537, which lie in close proximity within the $\mathrm{S}$ gene and the detection of one of the SNP allowed differentiation between FCoV from cats with FIP and healthy cats in $96 \%$ of the examined FCoV. In all of the sequenced fecal FCoV from healthy cats, adenine was found at nucleotide position 23531, whereas thymine or cytosine was detected in $92 \%$ of the FCoV from ascites or tissues of cats with FIP. Both SNP led to the substitution of methionine by leucine at amino acid position 1058 within the putative fusion peptide of the S protein (M1058L). In all of the sequenced fecal FCoV from healthy cats, thymine was detected at the second nucleotide position 
23537, whereas guanine was found in $4 \%$ of the FCoV from ascites or tissues of cats with FIP. This SNP led to the substitution of serine to alanine at position 1060 of the S protein (S1060A) [185].

\subsection{Tissue}

After that first study provided evidence of an association of the two $S$ gene mutations with FIP [185], a number of studies subsequently investigated the prevalence of the mutations in tissue samples from cats with and without FIP (Table 14).

Table 14. Sensitivity and specificity from different studies evaluating the detection of feline coronavirus (FCoV) spike (S) gene mutations in tissue samples. Feline infectious peritonitis (FIP) was confirmed by histopathology alone or in combination with immunohistochemistry (IHC), control cats were either healthy cats or cats with diseases other than FIP (with or without clinical signs consistent with FIP).

\begin{tabular}{|c|c|c|c|c|c|c|c|}
\hline Study & $\begin{array}{l}\text { Sample } \\
\text { Type }\end{array}$ & $\begin{array}{l}\text { Number of } \\
\text { Samples }\end{array}$ & Assay & Sensitivity & Specificity & $\begin{array}{l}\text { Reference } \\
\text { Standard for FIP }\end{array}$ & Control Cats \\
\hline [185] & $\begin{array}{l}\text { Tissue or } \\
\text { ascites }\end{array}$ & $\mathrm{FIP}(n=118)$ & $\begin{array}{l}\text { RT-nPCR plus S } \\
\text { gene sequencing }\end{array}$ & $96 \%$ & n. d. & Histopathology & None \\
\hline [137] & Tissue & $\begin{array}{l}\text { FIP }(n=47) \\
\text { Controls }(n=10)\end{array}$ & $\begin{array}{l}\text { RT-qPCR plus } \\
\text { pyrosequencing }\end{array}$ & $\begin{array}{l}91 \% \\
(\mathrm{M} 1058 \mathrm{~L})\end{array}$ & $11 \%$ & Histopathology/IHC & $\begin{array}{l}\text { Diseases other } \\
\text { than FIP }\end{array}$ \\
\hline [187] & Tissue & $\operatorname{FIP}(n=3)$ & $\begin{array}{l}\text { RT-qPCR plus } \\
\text { sequencing }\end{array}$ & $100 \%$ & n. d. & Histopathology/IHC & None \\
\hline [140] & $\begin{array}{l}\text { FNA of } \\
\text { various } \\
\text { tissues }\end{array}$ & $\operatorname{FIP}(n=9)$ & $\begin{array}{l}\text { RT-PCR plus } \\
\text { sequencing }\end{array}$ & $89 \%$ & n. d. & Histopathology & None \\
\hline [135] & Tissue & $\begin{array}{l}\text { FIP }(n=225) \\
\text { Controls }(n=258)\end{array}$ & $\begin{array}{l}\text { RT-qPCR plus } \\
\text { pyrosequencing } \pm \\
\text { Sanger sequencing }\end{array}$ & $81 \%$ & $95 \%$ & Histopathology/IHC & $\begin{array}{l}\text { Healthy or } \\
\text { diseases other } \\
\text { than FIP }\end{array}$ \\
\hline [15] & Tissue & $\begin{array}{l}\text { FIP }(n=10) \\
\text { Controls }(n=8)\end{array}$ & $\begin{array}{l}\text { RT-nPCR plus } \\
\text { sequencing }\end{array}$ & $70 \%$ & $88 \%$ & Histopathology/IHC & $\begin{array}{l}\text { Diseases other } \\
\text { than FIP }\end{array}$ \\
\hline [142] & $\begin{array}{l}\text { Pooled } \\
\text { tissues }\end{array}$ & $\begin{array}{l}\text { FIP }(n=34) \\
\text { Controls }(n=30)\end{array}$ & Real-time RT-PCR & $71 \%$ & $100 \%$ & Histopathology/IHC & $\begin{array}{l}\text { Diseases other } \\
\text { than FIP }\end{array}$ \\
\hline [141] & $\begin{array}{l}\text { FNA or IB } \\
\text { of various } \\
\text { tissues }\end{array}$ & $\mathrm{FIP}(n=20)$ & Real-time RT-PCR & $15-50 \%$ & n. d. & Histopathology/IHC & None \\
\hline
\end{tabular}

FNA = fine-needle aspirates; IB = incisional biopsies; $\mathrm{M} 1058 \mathrm{~L}=$ substitution of methionine to leucine at position 1058 of the FCoV S protein; $\mathrm{n}$. d. = not determined; RT-PCR = reverse transcriptase polymerase chain reaction; RT-nPCR = nested RT-PCR; RT-qPCR = quantitative RT-PCR.

Opinions vary substantially among researchers, especially on the specificity of $S$ gene mutations for the FIP phenotype. For example, one recent study corroborated the initial findings by detecting M1058L in three tissue samples (mesentery, colonic lymph node and omentum) from cats with FIP; moreover, the mutation fully discriminated the FCoV found in these tissue samples from FCoV found in fecal samples from healthy cats [187]. In contrast, FCoV with substitution M1058L was not specific for the FIP phenotype in a different study, which also found the mutation in tissue samples from cats without FIP. Not only the majority of FCoV from tissue samples from cats with FIP $(39 / 43 ; 91 \%)$, but also the majority of those from tissue samples from control cats without FIP $(8 / 9 ; 89 \%)$ had a leucine (and thus, a mutated sequence) at position 1058 in that study. On the other hand, the majority of FCoV from fecal samples from cats with (10/13; 77\%) and without FIP $(6 / 6 ; 100 \%)$ had a methionine (and thus, a non-mutated sequence) at this position. Additionally, a number of tissue samples from cats with FIP $(4 / 43 ; 9 \%)$ also exhibited a methionine at position 1058, which means that they did not contain a mutation despite being from cats with FIP. Therefore, the authors concluded that substitution M1058L was indicative of systemic spread of FCoV rather than a marker for FIP [137]. In this study, five tissue samples that did not contain the substitution M1058L were analyzed for substitution S1060A (the less common S gene mutation) by Sanger sequencing, and S1060A was then detected in $1 / 4$ samples from cats with FIP but not in the one remaining sample from a control cat [137].

Since the first description, PCR assays detecting mutations M1058L and S1060A frequently have been used for diagnostic purposes and a number of studies have evaluated sensitivity and specificity 
or diagnostic accuracy of the detection of the mutations in the diagnosis of FIP (Table 14). However, largely contrasting results were also found in these studies, especially in terms of specificity, possibly as a result of different sequencing assays that were used.

One study, for example, examined a large number of tissue, fluid and fecal samples from cats with immunohistochemically confirmed FIP and controls in which FIP was excluded and performed RT-qPCR followed by pyrosequencing of an S gene amplicon in the RT-qPCR-positive samples. In total, 260 tissue samples from cats with FIP were analyzed. However, since histopathological data was only available for 225 of the tissue samples, only these numbers were included in the calculation of sensitivity and specificity (Table 14). Of these 225 samples, 202 were RT-qPCR-positive and S gene mutations were detected in 182/202 samples (M1058L being much more common than S1060A; mixed mutated and non-mutated FCoV or FCoV with both M1058L and S1060A also present). Of the 258 tissue samples from control cats, 19 were RT-qPCR-positive and 14/19 were positive for mutation M1058L. When comparing sensitivity and specificity of RT-qPCR alone with that of RT-qPCR plus S gene sequencing, specificity slightly increased from $93 \%$ to $95 \%$, whereas sensitivity decreased from $90 \%$ to $81 \%$. Therefore, it was concluded that the detection of FCoV S gene mutations did not improve the ability to diagnose FIP. Mutations were also found in cats without FIP, which supported the hypothesis of the mutations being a marker for systemic spread of FCoV and not for FIP [135]. A somewhat similar result was obtained a year later when a study compared different laboratory tests in tissue samples (mesenteric lymph nodes, spleen, small intestine, lung) from cats with FIP (positive IHC in at least one tissue) and control cats (histopathological diagnosis of another disease plus negative IHC). All samples were examined by RT-nPCR targeting the highly conserved 3'-UTR and sequencing was performed to detect $S$ gene mutations. Again, the detection of FCoV S gene mutations improved specificity of the RT-nPCR from $50 \%$ to $88 \%$, but sensitivity decreased from $91 \%$ to $70 \%$, and an $\mathrm{S}$ gene mutation (type of mutation not shown) was also detected in a cat without FIP [15].

However, contrasting results were obtained when a real-time RT-PCR was developed and evaluated subsequently, which uses specific fluorescent hydrolysis probes to detect either one of the two SNP or the wildtype sequence. In that study, none of the 30 cats without FIP (with histopathological diagnosis plus negative IHC) tested positive for one of the $S$ gene mutations in their tissues. Of the 34 cats with immunohistochemically confirmed FIP, 24 tested positive for one of the $S$ gene mutations in at least one of their tissues (23/24 M1058L, one mixed genotype). In this study, sensitivity was $71 \%$ and as such comparable to the previous studies; however, specificity was excellent (100\%) [142]. Finally, a recent study evaluated the same real-time RT-PCR detecting $S$ gene mutations in 20 cats with immunohistochemically confirmed FIP. FNA and IB samples were obtained from the mesenteric and popliteal lymph nodes, spleen, liver, kidney and omentum and additionally from different body fluids. Samples were first examined by RT-PCR detecting the FCoV $7 \mathrm{~b}$ gene (detecting all FCoV) and RT-PCR-positive samples were subsequently analyzed by real-time RT-PCR detecting $S$ gene mutations. Interestingly, FCoV with S gene mutations was present in every cat, but the location of mutated FCoV varied from cat to cat. Sensitivity of the RT-PCR detecting all FCoV was good for all tissues except for the popliteal lymph nodes, but sensitivity decreased when $\mathrm{S}$ gene mutations were evaluated. Since sensitivity of FNA and IB did not significantly differ, sampling via minimally invasive FNA seems possible in order to obtain adequate samples for RT-PCR testing. Specificity was not determined in this study, since a control group was not included in the study protocol.

\subsection{Blood}

Diagnostic accuracy of the detection of FCoV S gene mutations has also been evaluated in blood samples (Table 15). RT-nPCR and subsequent $S$ gene sequencing of serum and plasma samples from cats with FIP (diagnosed by histopathology \pm IHC or by positive immunofluorescence in effusion) and control cats (diagnosed with another disease either ante or post mortem) revealed a sensitivity of only $7 \%$, which confirms the very low virus load in blood. RT-nPCR was negative in all of the blood samples from cats without FIP, and thus, specificity of the sequencing step could not be 
determined [156]. Subsequent studies evaluated the aforementioned real-time RT-PCR detecting S gene mutations by specific fluorescent hydrolysis probes in blood samples (plasma, serum, buffy coat, whole blood) from cats with FIP [141] and/or controls [157] (reference standard histopathology and IHC) and either did not detect mutated FCoV in any of the blood samples or only found very low sensitivity. In some cats with FIP, FCoV RNA was detected, but viral concentrations were too low to allow pathotyping [157]. This implicates that blood cannot be recommended as sample material. Nevertheless, a study comparing different PCR tests including 3'-UTR RT-nPCR and a combined approach with RT-PCR followed by $\mathrm{S}$ gene sequencing reported a sensitivity of $75 \%$ for the RT-nPCR and $43 \%$ for combined RT-PCR and sequencing when whole blood was used. Potentially, whole blood can give better results than plasma or serum. Although the authors state that specificity of both RT-nPCR and combined approach were $100 \%$, specificity of the sequencing step should not be calculated from that study, since none of the blood samples from cats without FIP tested positive for FCoV RNA at all [15].

Table 15. Sensitivity and specificity from different studies evaluating the detection of feline coronavirus $(\mathrm{FCoV})$ spike (S) gene mutations in blood samples. Feline infectious peritonitis (FIP) was confirmed by histopathology alone, in combination with immunohistochemistry (IHC) or by positive immunostaining of FCoV antigen in effusion. Control cats were cats with diseases other than FIP (with clinical signs consistent with FIP).

\begin{tabular}{|c|c|c|c|c|c|c|c|}
\hline Study & Sample Type & $\begin{array}{l}\text { Number of } \\
\text { Samples }\end{array}$ & Assay & Sensitivity & Specificity & $\begin{array}{l}\text { Reference Standard } \\
\text { for FIP }\end{array}$ & $\begin{array}{l}\text { Control } \\
\text { Cats }\end{array}$ \\
\hline [156] & Serum/plasma & $\begin{array}{l}\text { FIP }(n=31) \\
\text { Controls }(n=21)\end{array}$ & $\begin{array}{l}\text { RT-nPCR plus } \\
\text { S gene } \\
\text { sequencing }\end{array}$ & $7 \%$ & n. d. & $\begin{array}{l}\text { Histopathology, IHC } \\
\text { or detection of FCoV } \\
\text { antigen in effusion }\end{array}$ & $\begin{array}{l}\text { Diseases } \\
\text { other than } \\
\text { FIP }\end{array}$ \\
\hline [157] & Serum/plasma & $\begin{array}{l}\mathrm{FIP}(n=14) \\
\text { Controls }(n=3)\end{array}$ & $\begin{array}{l}\text { Real-time } \\
\text { RT-PCR }\end{array}$ & $0 \%$ & n. d. & $\begin{array}{l}\text { Histopathology } \\
\text { and/or IHC }\end{array}$ & $\begin{array}{l}\text { Diseases } \\
\text { other than } \\
\text { FIP }\end{array}$ \\
\hline [15] & Whole blood & $\begin{array}{l}\text { FIP }(n=7) \\
\text { Controls }(n=7)\end{array}$ & $\begin{array}{l}\text { RT-nPCR plus } \\
\text { S gene } \\
\text { sequencing }\end{array}$ & $43 \%$ & n. d. & Histopathology/IHC & $\begin{array}{l}\text { Diseases } \\
\text { other than } \\
\text { FIP }\end{array}$ \\
\hline [141] & $\begin{array}{l}\text { Buffy coat, serum } \\
\text { or whole blood }\end{array}$ & $\operatorname{FIP}(n=20)$ & $\begin{array}{l}\text { Real-time } \\
\text { RT-PCR }\end{array}$ & $0-23 \%$ & n. d. & Histopathology/IHC & None \\
\hline
\end{tabular}

n. d. = not determined; RT-PCR = reverse transcriptase polymerase chain reaction; RT-nPCR = nested RT-PCR.

\subsection{Effusion}

An association of substitutions M1058L and S1060A with FIP was shown by a study which detected amino acid substitution M1058L in 83\% FCoV extracted from ascites of cats with FIP (reference standard for the diagnosis not reported) and a non-mutated sequence (a methionine codon) in $90 \%$ FCoV extracted from feces of healthy cats and $57 \%$ FCoV extracted from feces of cats with FIP [170]. However, contrasting results of PCR assays detecting FCoV S gene mutations were again, as in tissue and blood, found subsequently when analyzing effusion and other fluid samples for diagnostic purposes (Table 16).

One study including cats with FIP confirmed by IHC and control cats classified as non-FIP by confirmation of other diseases based on either histopathology and/or the definitive diagnosis of another disease ante mortem showed that RT-qPCR alone had a sensitivity of $85 \%$ and a specificity of $100 \%$. Of the 17 RT-qPCR-positive cats, 11 had a mutated FCoV with substitution M1058L in their effusion detected by sequencing. One cat exhibited mutation S1060A. This resulted in a sensitivity of $60 \%$ for the detection of $S$ gene mutations. Since none of the control cats were RT-qPCR positive, specificity of the sequencing step could not be determined. Thus, the majority of effusion samples that generated sequence data contained a mutated $\mathrm{FCoV}$, although in that study population, detection of $\mathrm{S}$ gene mutations did not improve specificity [160]. When an RT-nPCR and subsequent $S$ gene sequencing was used on effusion samples from cats with FIP (diagnosed by histopathology \pm IHC or by positive immunofluorescence in effusion) and control cats (diagnosed with another disease either ante or post 
mortem), a similarly moderate sensitivity of $65 \%$ was detected. Of the 50 samples from cats with FIP, 36 were RT-nPCR-positive, and the majority of those (32/36) contained S gene mutations (M1058L $n=$ 30 , S1060A $n=2)$. RT-nPCR was negative in all of effusion samples from cats without FIP, and thus, specificity of the sequencing step again could not be determined [156]. Evaluations of a real-time RT-PCR detecting the $S$ gene mutations with specific fluorescent hydrolysis probes in effusion from cats with FIP and controls (reference standard histopathology and IHC) detected similar sensitivities of $64-69 \%$ for the detection of $S$ gene mutations $[141,157]$. Of the 35 samples from cats with FIP in one study, 34 were RT-PCR-positive. Mutated FCoV containing M1058L was detected in the majority of samples (22/34). Additionally, mixed FCoV (with and without $\mathrm{S}$ gene mutations) were detected in two cats. In 10 cats, RT-PCR was positive, but RT-PCR detecting $S$ gene mutations was not successful, either because of a low virus load $(n=7)$ or despite a high virus load $(n=3)$. The reason for the latter could be the presence of unknown sequence variations or serotype II FCoV. RT-PCR was also positive in 3/24 effusion samples from cats without FIP and M1058L was detected in one ascites sample from a cat with chronic kidney disease [157]. Finally, one recent study collected different body fluids (CSF, aqueous humor, ascites, pleural or pericardial effusion) from cats with FIP (confirmed by IHC) and cats in which histopathological signs of FIP were absent. Of the 51 samples from cats with FIP, 40 were RT-qPCR-positive. In a subsequent pyrosequencing step, 30 of these 50 (one sample was lost from S gene analysis) contained mutated FCoV (M1058L $n=25$, S1060A $n=1$, mixed mutated and non-mutated FCoV without differentiation of mutation $n=4)$. Of the 47 fluid samples from cats without FIP, one was RT-qPCR-positive and contained substitution M1058L (an abdominal fluid sample from a cat with necrotizing pneumonia). Since individual results for effusion, CSF and aqueous humor are not shown in that study, sensitivity and specificity cannot be calculated individually, but only for all fluid samples together (Table 16). As was demonstrated for tissue samples, the detection of $S$ gene mutations in this study led to a decrease in sensitivity ( $78 \%$ for RT-qPCR alone compared with $60 \%$ for combined approach) and an S gene mutation was also detected in a cat without FIP [135].

Table 16. Sensitivity and specificity from different studies evaluating the detection of feline coronavirus (FCoV) spike (S) gene mutations in effusion samples. Feline infectious peritonitis (FIP) was confirmed by histopathology alone, in combination with immunohistochemistry (IHC) or by immunostaining of FCoV antigen in effusion. Control cats were either healthy cats or cats with diseases other than FIP (with or without clinical signs consistent with FIP).

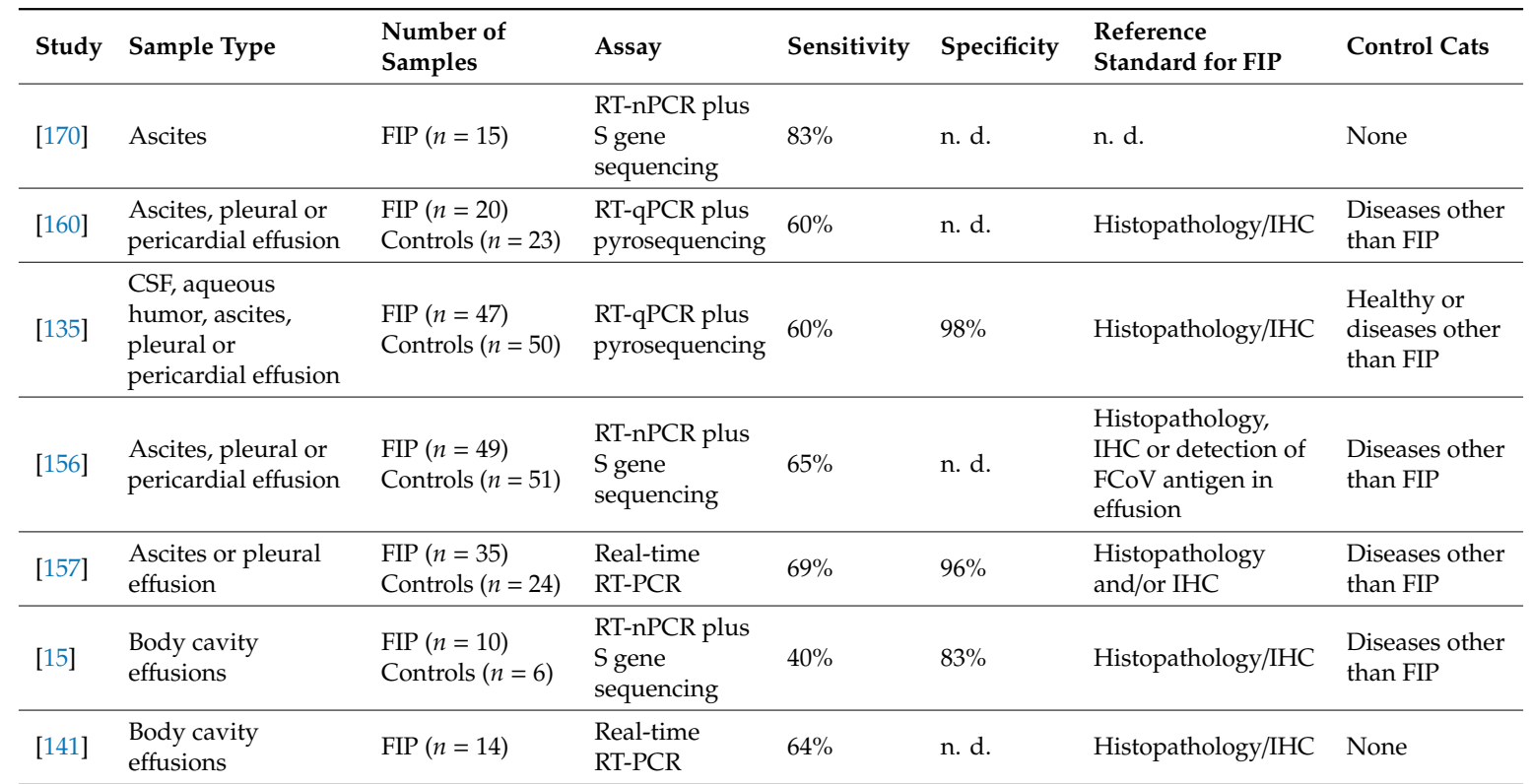

$\mathrm{CSF}=$ cerebrospinal fluid; $\mathrm{n}$. d. = not determined; RT-PCR = reverse transcriptase polymerase chain reaction; RT-nPCR = nested RT-PCR; RT-qPCR = quantitative RT-PCR. 


\subsection{CSF}

The detection of FCoV S gene mutations in CSF was evaluated in two studies presented as conference abstracts thus far (Table 17). One study obtained 16 CSF samples from cats with FIP (confirmed by IHC) and reported a sensitivity of $44 \%$. Control cats were not included in that study [141]. The other study looked at 31 cats with immunohistochemically confirmed FIP (six with neurological signs) and 29 control cats with clinical signs indicative of FIP (10 with neurological signs) but definitively diagnosed other diseases, and calculated a sensitivity of $10 \%$. Sensitivity increased to $17 \%$ if only cats with neurological signs were included. Since FCoV RNA was not detected in any of the control cats, specificity of the detection of $S$ gene mutations could not be calculated [188].

Table 17. Sensitivity and specificity from studies evaluating the detection of feline coronavirus (FCoV) spike (S) gene mutations in cerebrospinal fluid (CSF) samples. Feline infectious peritonitis (FIP) was confirmed by histopathology and immunohistochemistry (IHC). Control cats, if present, were cats with diseases other than FIP (with clinical signs consistent with FIP).

\begin{tabular}{|c|c|c|c|c|c|c|c|}
\hline Study & $\begin{array}{l}\text { Sample } \\
\text { Type }\end{array}$ & $\begin{array}{l}\text { Number of } \\
\text { Samples }\end{array}$ & Assay & Sensitivity & Specificity & $\begin{array}{l}\text { Reference } \\
\text { Standard for FIP }\end{array}$ & $\begin{array}{l}\text { Control } \\
\text { Cats }\end{array}$ \\
\hline [188] & CSF & $\begin{array}{l}\text { FIP }(n=31) \\
\text { Controls }(n=29)\end{array}$ & $\begin{array}{l}\text { Real-time } \\
\text { RT-PCR }\end{array}$ & $10 \%$ & n. d. & Histopathology/IHC & $\begin{array}{l}\text { Diseases } \\
\text { other than } \\
\text { FIP }\end{array}$ \\
\hline [188] & CSF & $\begin{array}{l}\text { FIP with } \\
\text { neurological } \\
\text { signs }(n=6) \\
\text { Controls with } \\
\text { neurological } \\
\text { signs }(n=10)\end{array}$ & $\begin{array}{l}\text { Real-time } \\
\text { RT-PCR }\end{array}$ & $17 \%$ & n. d. & Histopathology/IHC & $\begin{array}{l}\text { Diseases } \\
\text { other than } \\
\text { FIP }\end{array}$ \\
\hline [141] & CSF & $\operatorname{FIP}(n=16)$ & $\begin{array}{l}\text { Real-time } \\
\text { RT-PCR }\end{array}$ & $44 \%$ & n. d. & Histopathology/IHC & None \\
\hline
\end{tabular}

n. d. = not determined; RT-PCR = reverse transcriptase polymerase chain reaction.

\subsection{Aqueous Humor}

Only two studies that were presented as conference abstracts have evaluated sensitivity and specificity of the detection of FCoV S gene mutations in aqueous humor (Table 18). These studies included cats with FIP confirmed by IHC and reported sensitivities of only 10-17\%. Specificity, however, could not be calculated in either one of the studies, either because no control cats were included or because none of the control cats were FCoV-positive at all [141,164].

Table 18. Sensitivity and specificity from different studies evaluating the detection of feline coronavirus $(\mathrm{FCoV})$ spike (S) gene mutations in aqueous humor samples. Feline infectious peritonitis (FIP) was confirmed by histopathology and immunohistochemistry (IHC). Control cats, if present, were cats with diseases other than FIP (with clinical signs consistent with FIP).

\begin{tabular}{llllllll}
\hline Study & $\begin{array}{l}\text { Sample } \\
\text { Type }\end{array}$ & $\begin{array}{l}\text { Number of } \\
\text { Samples }\end{array}$ & Assay & Sensitivity & Specificity & $\begin{array}{l}\text { Reference } \\
\text { Standard for FIP }\end{array}$ & $\begin{array}{l}\text { Control } \\
\text { Cats }\end{array}$ \\
\hline$[141]$ & $\begin{array}{l}\text { Aqueous } \\
\text { humor }\end{array}$ & FIP $(n=20)$ & $\begin{array}{l}\text { Real-time } \\
\text { RT-PCR }\end{array}$ & $10 \%$ & n. d. & Histopathology/IHC & None \\
\hline [164] & $\begin{array}{l}\text { Aqueous } \\
\text { humor }\end{array}$ & $\begin{array}{l}\text { FIP }(n=25) \\
\text { Controls }(n=11)\end{array}$ & $\begin{array}{l}\text { Real-time } \\
\text { RT-PCR }\end{array}$ & $17 \%$ & n. d. & Histopathology/IHC & $\begin{array}{l}\text { Diseases } \\
\text { other than } \\
\text { FIP }\end{array}$ \\
\hline
\end{tabular}

n. d. = not determined; RT-PCR = reverse transcriptase polymerase chain reaction. 


\section{Conclusions}

Ante mortem diagnosis of FIP cannot be made based on results of one single diagnostic test. It is important to consider signalment, history, clinical signs and standard clinicopathological abnormalities in every cat that is presented with a suspicion of FIP. Additional tests, especially tests for direct virus detection, should be utilized depending on the clinical picture. Measurement of FCoV antibodies is not useful for the diagnosis at all. Routine hematology, serum biochemistry and, if present, analysis of effusion should be performed in every cat. In cats with neurological clinical signs, CSF analysis should be done as well. Diagnostic trees depicting relevant additional diagnostic steps that are recommended depending on a cat's clinical presentation are shown in Figure 1. In cats with effusion, laboratory analysis of the fluid including Rivalta's test should be performed. If this test is negative, FIP is rather unlikely, especially if the pre-test probability of FIP is low. If Rivalta's test is positive, however, further diagnostic steps should follow. RT-PCR on effusion can help in establishing a diagnosis, especially if viral copy numbers are high. A negative RT-PCR on effusion makes FIP unlikely, unless suspicion is high based on clinical findings and other laboratory test results. High FCoV load or detection of $S$ gene mutations in an RT-PCR-positive effusion sample can substantiate a suspicion of FIP. Additionally, in order to increase sensitivity of the detection of $S$ gene mutations, other sample material, such as FNA of mesenteric lymph nodes, spleen and liver and whole blood can be included in the analysis. If, however, $\mathrm{S}$ gene mutations cannot be detected in an RT-PCR-positive sample and the virus load is low, but still the suspicion of FIP is high in a case, then more invasive diagnostic procedures, such as histopathology and IHC on tissue samples obtained in laparotomy/laparoscopy should be considered in order to confirm or exclude FIP.

In cats presenting without significant effusion, analysis of different sample types should be combined. Ultrasound-guided FNA of different organs including the mesenteric lymph nodes, spleen and liver can provide sample material for general RT-PCR, which should be the first diagnostic test in such a case. In cats with neurological clinical signs, diagnostic imaging and CSF sampling is an important step in reaching a diagnosis anyway and CSF should be submitted for RT-PCR as well. The same is true for cats with uveitis in which the aqueous humor should be integrated in a set of different samples for analysis by RT-PCR. By testing several materials, sensitivity of any given test can be increased. If general RT-PCR is positive in a cat without effusion, then again, the presence of FCoV S gene mutations or a high FCoV load might aid in cases of uncertainty-if mutations can be detected in an RT-PCR-positive sample, especially if copy numbers and pre-test probability of FIP are high, then FIP is likely. However, if $S$ gene mutations cannot be detected in the set of samples or if general RT-PCR on the samples submitted is negative or virus load is low, then other causes for FIP should be ruled out as far as possible. If the suspicion of FIP is still high (based on signalment, clinical and other laboratory findings) in a case with negative RT-PCR or a case lacking $S$ gene mutations, then histopathology and IHC on tissue samples must be considered in order to reach a definitive diagnosis.

However, as long as there is uncertainty regarding the putative role of $S$ gene or other mutations in FIP pathogenesis, and since specificity of RT-PCR in any given sample is not absolute, an ideal diagnostic test for FIP still does not exist. IHC on histopathologically abnormal tissue obtained either post mortem or via laparotomy/laparoscopy still remains the gold standard of diagnosis. 


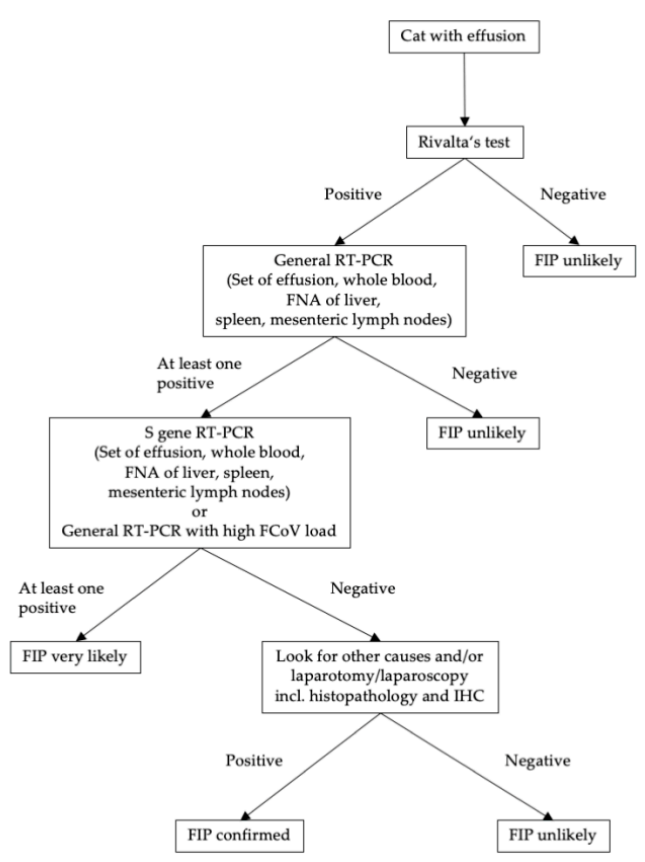

(a)

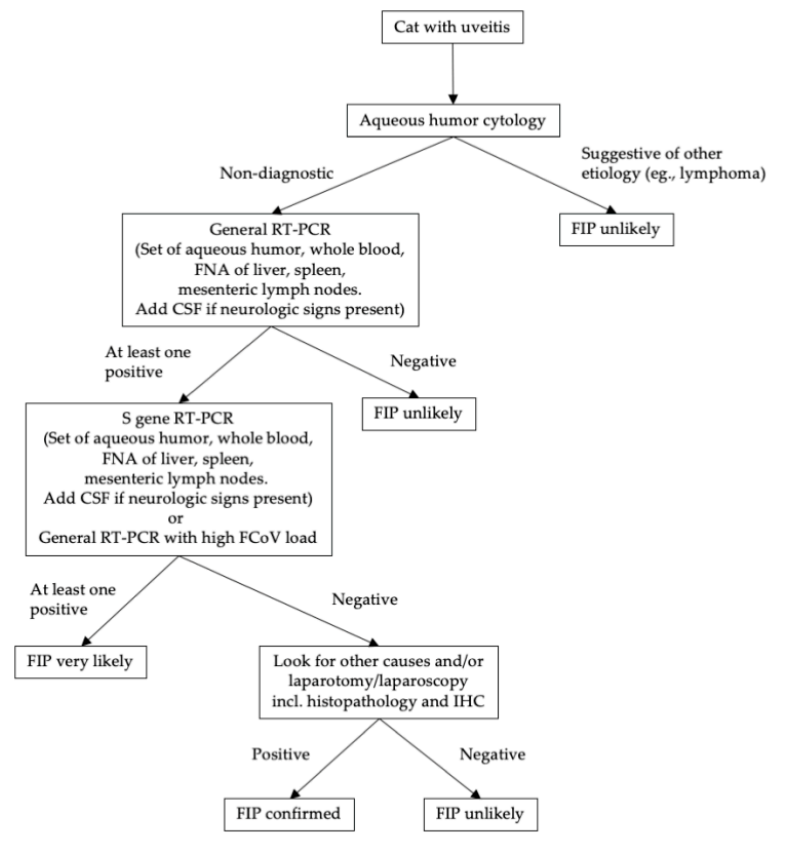

(c)

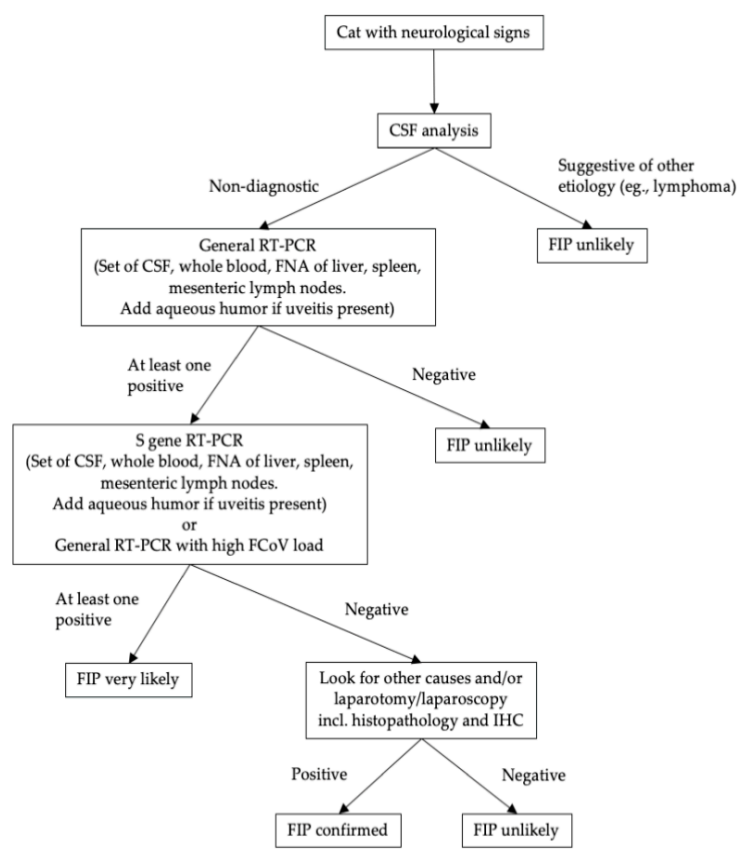

(b)

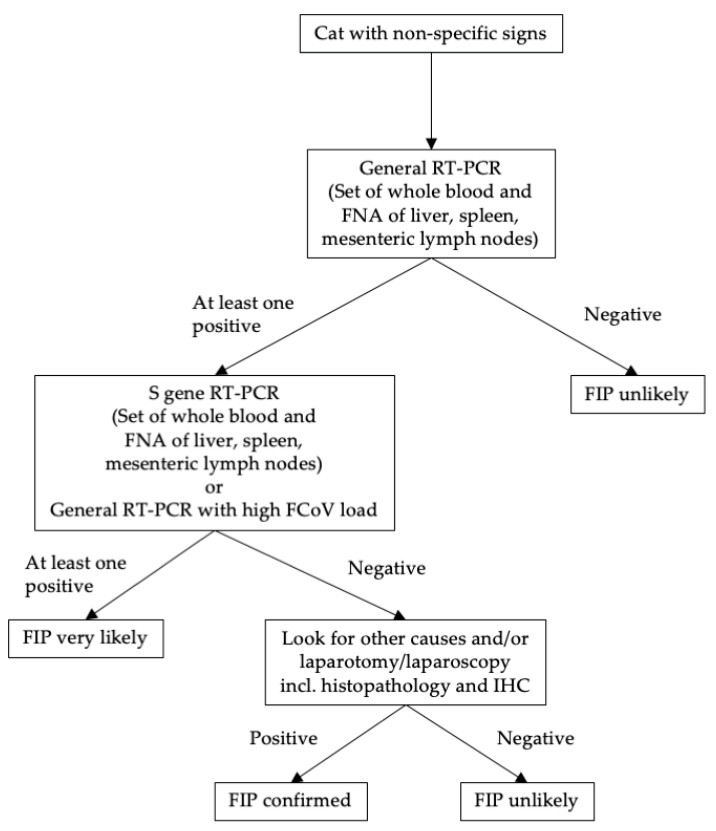

(d)

Figure 1. Decision trees depicting recommended diagnostic steps in a case suspicious of FIP, depending on a cat's clinical presentation: (a) diagnostic steps recommended in a cat presenting with effusion; (b) diagnostic steps recommended in a cat presenting with neurological signs; (c) diagnostic steps recommended in a cat presenting with uveitis; (d) diagnostic steps recommended in a cat presenting with non-specific clinical signs. CSF = cerebrospinal fluid; FCoV = feline coronavirus; FIP = feline infectious peritonitis; FNA = fine-needle aspirates; IHC = immunohistochemistry; RT-PCR = reverse transcriptase polymerase chain reaction; $S$ gene $=$ spike gene. 
Funding: This research received no external funding.

Conflicts of Interest: Katrin Hartmann has given talks for MSD, Merial, Boehringer Ingelheim and Idexx. She participated in research funded by or using products from MSD, Merial, Boehringer, Zoetis, Megacor, Biogal and Scil. There is no commercial conflict of interest as the information generated here is solely for scientific dissemination. The authors declare that they have no competing interests.

\section{References}

1. Pedersen, N.C.; Allen, C.E.; Lyons, L.A. Pathogenesis of feline enteric coronavirus infection. J. Feline Med. Surg. 2008, 10, 529-541. [CrossRef] [PubMed]

2. Pedersen, N.C.; Sato, R.; Foley, J.E.; Poland, A.M. Common virus infections in cats, before and after being placed in shelters, with emphasis on feline enteric coronavirus. J. Feline Med. Surg. 2004, 6, 83-88. [CrossRef] [PubMed]

3. Vogel, L.; Van der Lubben, M.; te Lintelo, E.G.; Bekker, C.P.; Geerts, T.; Schuijff, L.S.; Grinwis, G.C.; Egberink, H.F.; Rottier, P.J. Pathogenic characteristics of persistent feline enteric coronavirus infection in cats. Vet. Res. 2010, 41, 71-82. [CrossRef]

4. Vennema, H.; Poland, A.; Foley, J.; Pedersen, N.C. Feline infectious peritonitis viruses arise by mutation from endemic feline enteric coronaviruses. Virology 1998, 243, 150-157. [CrossRef] [PubMed]

5. Pedersen, N.C.; Boyle, J.F.; Floyd, K. Infection studies in kittens, using feline infectious peritonitis virus propagated in cell culture. Am. J. Vet. Res. 1981, 42, 363-367. [PubMed]

6. Pedersen, N.C.; Boyle, J.F.; Floyd, K.; Fudge, A.; Barker, J. An enteric coronavirus infection of cats and its relationship to feline infectious peritonitis. Am. J. Vet. Res. 1981, 42, 368-377. [PubMed]

7. Riemer, F.; Kuehner, K.A.; Ritz, S.; Sauter-Louis, C.; Hartmann, K. Clinical and laboratory features of cats with feline infectious peritonitis-a retrospective study of 231 confirmed cases (2000-2010). J. Feline Med. Surg. 2016, 18, 348-356. [CrossRef]

8. Pesteanu-Somogyi, L.D.; Radzai, C.; Pressler, B.M. Prevalence of feline infectious peritonitis in specific cat breeds. J. Feline Med. Surg. 2006, 8, 1-5. [CrossRef]

9. Rohrbach, B.W.; Legendre, A.M.; Baldwin, C.A.; Lein, D.H.; Reed, W.M.; Wilson, R.B. Epidemiology of feline infectious peritonitis among cats examined at veterinary medical teaching hospitals. J. Am. Vet. Med. Assoc. 2001, 218, 1111-1115. [CrossRef]

10. Foley, J.; Pedersen, N. The inheritance of susceptibility to feline infectious peritonitis in purebred catteries. Feline Pract. 1996, 24, 14-22.

11. Giori, L.; Giordano, A.; Giudice, C.; Grieco, V.; Paltrinieri, S. Performances of different diagnostic tests for feline infectious peritonitis in challenging clinical cases. J. Small Anim. Pract. 2011, 52, 152-157. [CrossRef] [PubMed]

12. Pedersen, N.C. A review of feline infectious peritonitis virus infection: 1963-2008. J. Feline Med. Surg. 2009, 11, 225-258. [CrossRef] [PubMed]

13. Kipar, A.; Meli, M.L. Feline infectious peritonitis: Still an enigma? Vet. Pathol. 2014, 51, 505-526. [CrossRef] [PubMed]

14. Singh, M.; Foster, D.J.; Child, G.; Lamb, W.A. Inflammatory cerebrospinal fluid analysis in cats: Clinical diagnosis and outcome. J. Feline Med. Surg. 2005, 7, 77-93. [CrossRef]

15. Stranieri, A.; Giordano, A.; Paltrinieri, S.; Giudice, C.; Cannito, V.; Lauzi, S. Comparison of the performance of laboratory tests in the diagnosis of feline infectious peritonitis. J. Vet. Diagn. Investig. 2018, 30, 459-463. [CrossRef] [PubMed]

16. Hartmann, K.; Binder, C.; Hirschberger, J.; Cole, D.; Reinacher, M.; Schroo, S.; Frost, J.; Egberink, H.; Lutz, H.; Hermanns, W. Comparison of different tests to diagnose feline infectious peritonitis. J. Vet. Intern. Med. 2003, 17, 781-790. [CrossRef]

17. Paltrinieri, S.; Comazzi, S.; Spagnolo, V.; Giordano, A. Laboratory changes consistent with feline infectious peritonitis in cats from multicat environments. J. Vet. Med. A. Physiol. Pathol. Clin. Med. 2002, 49, 503-510. [CrossRef]

18. Paltrinieri, S.; Grieco, V.; Comazzi, S.; Cammarata Parodi, M. Laboratory profiles in cats with different pathological and immunohistochemical findings due to feline infectious peritonitis (fip). J. Feline Med. Surg. 2001, 3, 149-159. [CrossRef] 
19. Sparkes, A.H.; Gruffydd-Jones, T.J.; Harbour, D.A. Feline infectious peritonitis: A review of clinicopathological changes in 65 cases, and a critical assessment of their diagnostic value. Vet. Rec. 1991, 129, 209-212. [CrossRef]

20. Sparkes, A.H.; Gruffydd-Jones, T.J.; Harbour, D.A. An appraisal of the value of laboratory tests in the diagnosis of feline infectious peritonitis. J. Am. Anim. Hosp. Assoc. 1994, 30, 345-350.

21. Norris, J.M.; Bosward, K.L.; White, J.D.; Baral, R.M.; Catt, M.J.; Malik, R. Clinicopathological findings associated with feline infectious peritonitis in sydney, australia: 42 cases (1990-2002). Aust. Vet. J. 2005, 83, 666-673. [CrossRef] [PubMed]

22. Tsai, H.Y.; Chueh, L.L.; Lin, C.N.; Su, B.L. Clinicopathological findings and disease staging of feline infectious peritonitis: 51 cases from 2003 to 2009 in taiwan. J. Feline Med. Surg. 2011, 13, 74-80. [CrossRef] [PubMed]

23. Jeffery, U.; Deitz, K.; Hostetter, S. Positive predictive value of albumin: Globulin ratio for feline infectious peritonitis in a mid-western referral hospital population. J. Feline Med. Surg. 2012, 14, 903-905. [CrossRef] [PubMed]

24. Taylor, S.S.; Tappin, S.W.; Dodkin, S.J.; Papasouliotis, K.; Casamian-Sorrosal, D.; Tasker, S. Serum protein electrophoresis in 155 cats. J. Feline Med. Surg. 2010, 12, 643-653. [CrossRef]

25. Duthie, S.; Eckersall, P.D.; Addie, D.D.; Lawrence, C.E.; Jarrett, O. Value of alpha 1-acid glycoprotein in the diagnosis of feline infectious peritonitis. Vet. Rec. 1997, 141, 299-303. [CrossRef]

26. Giordano, A.; Spagnolo, V.; Colombo, A.; Paltrinieri, S. Changes in some acute phase protein and immunoglobulin concentrations in cats affected by feline infectious peritonitis or exposed to feline coronavirus infection. Vet. J. 2004, 167, 38-44. [CrossRef]

27. Hazuchova, K.; Held, S.; Neiger, R. Usefulness of acute phase proteins in differentiating between feline infectious peritonitis and other diseases in cats with body cavity effusions. J. Feline Med. Surg. 2017, 19, 809-816. [CrossRef]

28. Paltrinieri, S.; Giordano, A.; Tranquillo, V.; Guazzetti, S. Critical assessment of the diagnostic value of feline alpha1-acid glycoprotein for feline infectious peritonitis using the likelihood ratios approach. J. Vet. Diagn. Investig. 2007, 19, 266-272.

29. Selting, K.A.; Ogilvie, G.K.; Lana, S.E.; Fettman, M.J.; Mitchener, K.L.; Hansen, R.A.; Richardson, K.L.; Walton, J.A.; Scherk, M.A. Serum alhpa 1-acid glycoprotein concentrations in healthy and tumor-bearing cats. J. Vet. Intern. Med. 2000, 14, 503-506.

30. Ceron, J.J.; Eckersall, P.D.; Martynez-Subiela, S. Acute phase proteins in dogs and cats: Current knowledge and future perspectives. Vet. Clin. Pathol. 2005, 34, 85-99. [CrossRef]

31. Paltrinieri, S.; Metzger, C.; Battilani, M.; Pocacqua, V.; Gelain, M.E.; Giordano, A. Serum alpha1-acid glycoprotein (agp) concentration in non-symptomatic cats with feline coronavirus (fcov) infection. J. Feline Med. Surg. 2007, 9, 271-277. [CrossRef] [PubMed]

32. Paltrinieri, S.; Marchini, I.; Gelain, M.E. Flow cytometric detection of alpha-1-acid glycoprotein on feline circulating leucocytes. Aust. Vet. J. 2012, 90, 291-296. [CrossRef] [PubMed]

33. Fischer, Y.; Wess, G.; Hartmann, K. Pericardial effusion in a cat with feline infectious peritonitis. Schweizer Archiv Tierheilkunde 2012, 154, 27-31. [CrossRef] [PubMed]

34. Pedersen, N.C. An update on feline infectious peritonitis: Diagnostics and therapeutics. Vet. J. 2014, 201, 133-141. [CrossRef] [PubMed]

35. Hirschberger, J. Cytology of body cavity effusions. Tierärztliche Prax. 1995, 23, 192-199.

36. Hirschberger, J.; Koch, S. Validation of the determination of the activity of adenosine deaminase in the body effusions of cats. Res. Vet. Sci. 1995, 59, 226-229. [CrossRef]

37. Hirschberger, J.; Sauer, G. Clinical and chemical investigations of body cavity effusions. Tieraerztliche Prax. 1991, 19, 431-434.

38. Shelly, S.; Scarlett-Kranz, J.; Blue, J. Protein electrophoresis on effusions from cats as a diagnostic test for feline infectious peritonitis. J. Am. Anim. Hosp. Assoc. 1988, 24, 495-500.

39. Fischer, Y.; Sauter-Louis, C.; Hartmann, K. Diagnostic accuracy of the rivalta test for feline infectious peritonitis. Vet. Clin. Pathol. 2012, 41, 558-567. [CrossRef]

40. Berti-Bock, G.; Vial, F.; Premuda, L.; Rulliere, R. Exudates, transudates and the rivalta reaction (1895). Current status and historical premises. Minerva. Med. 1979, 70, 3573-3580.

41. Giordano, A.; Stranieri, A.; Rossi, G.; Paltrinieri, S. High diagnostic accuracy of the sysmex xt-2000iv delta total nucleated cells on effusions for feline infectious peritonitis. Vet. Clin. Pathol. 2015, 44, 295-302. [CrossRef] [PubMed] 
42. Stranieri, A.; Paltrinieri, S.; Giordano, A. Diagnosing feline infectious peritonitis using the sysmex xt-2000iv based on frozen supernatants from cavitary effusions. J. Vet. Diagn. Investig. 2017, 29, 321-324. [CrossRef] [PubMed]

43. Crawford, A.H.; Stoll, A.L.; Sanchez-Masian, D.; Shea, A.; Michaels, J.; Fraser, A.R.; Beltran, E. Clinicopathologic features and magnetic resonance imaging findings in 24 cats with histopathologically confirmed neurologic feline infectious peritonitis. J. Vet. Intern. Med. 2017, 31, 1477-1486. [CrossRef] [PubMed]

44. Steinberg, T.A.; Boettcher, I.C.; Matiasek, K.; Hirschvogel, K.; Hartmann, K.; Kunz, A.; Fischer, A. Use of albumin quotient and igg index to differentiate blood- vs brain-derived proteins in the cerebrospinal fluid of cats with feline infectious peritonitis. Vet. Clin. Pathol. 2008, 37, 207-216. [CrossRef] [PubMed]

45. Foley, J.E.; Lapointe, J.M.; Koblik, P.; Poland, A.; Pedersen, N.C. Diagnostic features of clinical neurologic feline infectious peritonitis. J. Vet. Intern. Med. 1998, 12, 415-423. [CrossRef] [PubMed]

46. Boettcher, I.C.; Steinberg, T.; Matiasek, K.; Greene, C.E.; Hartmann, K.; Fischer, A. Use of anti-coronavirus antibody testing of cerebrospinal fluid for diagnosis of feline infectious peritonitis involving the central nervous system in cats. J. Am. Vet. Med. Assoc. 2007, 230, 199-205. [CrossRef]

47. Ziolkowska, N.; Pazdzior-Czapula, K.; Lewczuk, B.; Mikulska-Skupien, E.; Przybylska-Gornowicz, B.; Kwiecinska, K.; Ziolkowski, H. Feline infectious peritonitis: Immunohistochemical features of ocular inflammation and the distribution of viral antigens in structures of the eye. Vet. Pathol. 2017, 54, 933-944. [CrossRef]

48. Doherty, M.J. Ocular manifestations of feline infectious peritonitis. J. Am. Vet. Med. Assoc. 1971, 159, $417-424$.

49. Peiffer, R.L., Jr.; Wilcock, B.P. Histopathologic study of uveitis in cats: 139 cases (1978-1988). J. Am. Vet. Med. Assoc. 1991, 198, 135-138.

50. Linn-Pearl, R.N.; Powell, R.M.; Newman, H.A.; Gould, D.J. Validity of aqueocentesis as a component of anterior uveitis investigation in dogs and cats. Vet. Ophthalmol. 2015, 18, 326-334. [CrossRef]

51. Wiggans, K.T.; Vernau, W.; Lappin, M.R.; Thomasy, S.M.; Maggs, D.J. Diagnostic utility of aqueocentesis and aqueous humor analysis in dogs and cats with anterior uveitis. Vet. Ophthalmol. 2014, 17, 212-220. [CrossRef]

52. Lappin, M.R. Feline infectious uveitis. J. Feline Med. Surg. 2000, 2, 159-163. [CrossRef]

53. Kipar, A.; Bellmann, S.; Gunn-Moore, D.A.; Leukert, W.; Kohler, K.; Menger, S.; Reinacher, M. Histopathological alterations of lymphatic tissues in cats without feline infectious peritonitis after long-term exposure to fip virus. Vet. Microbiol. 1999, 69, 131-137. [CrossRef]

54. Meli, M.; Kipar, A.; Muller, C.; Jenal, K.; Gonczi, E.; Borel, N.; Gunn-Moore, D.; Chalmers, S.; Lin, F.; Reinacher, M.; et al. High viral loads despite absence of clinical and pathological findings in cats experimentally infected with feline coronavirus (fcov) type i and in naturally fcov-infected cats. J. Feline Med. Surg. 2004, 6, 69-81. [CrossRef]

55. Gunn-Moore, D.A.; Caney, S.M.; Gruffydd-Jones, T.J.; Helps, C.R.; Harbour, D.A. Antibody and cytokine responses in kittens during the development of feline infectious peritonitis (fip). Vet. Immunol. Immunopathol. 1998, 65, 221-242. [CrossRef]

56. Pedersen, N.C.; Boyle, J.F. Immunologic phenomena in the effusive form of feline infectious peritonitis. Am. J. Vet. Res. 1980, 41, 868-876.

57. Pedersen, N.C.; Eckstrand, C.; Liu, H.; Leutenegger, C.; Murphy, B. Levels of feline infectious peritonitis virus in blood, effusions, and various tissues and the role of lymphopenia in disease outcome following experimental infection. Vet. Microbiol. 2015, 175, 157-166. [CrossRef]

58. Desmarets, L.M.; Vermeulen, B.L.; Theuns, S.; Conceicao-Neto, N.; Zeller, M.; Roukaerts, I.D.; Acar, D.D.; Olyslaegers, D.A.; Van Ranst, M.; Matthijnssens, J.; et al. Experimental feline enteric coronavirus infection reveals an aberrant infection pattern and shedding of mutants with impaired infectivity in enterocyte cultures. Sci. Rep. 2016, 6, 20022. [CrossRef]

59. Stoddart, M.E.; Whicher, J.T.; Harbour, D.A. Cats inoculated with feline infectious peritonitis virus exhibit a biphasic acute phase plasma protein response. Vet. Rec. 1988, 123, 622-624.

60. Pedersen, N.C. Serologic studies of naturally occurring feline infectious peritonitis. Am. J. Vet. Res. 1976, 37, 1449-1453.

61. Addie, D.D.; Jarrett, O. Feline coronavirus antibodies in cats. Vet. Rec. 1992, 131, 202-203. [CrossRef] [PubMed] 
62. Addie, D.D.; le Poder, S.; Burr, P.; Decaro, N.; Graham, E.; Hofmann-Lehmann, R.; Jarrett, O.; McDonald, M.; Meli, M.L. Utility of feline coronavirus antibody tests. J. Feline Med. Surg. 2015, 17, 152-162. [CrossRef] [PubMed]

63. Osterhaus, A.D.; Horzinek, M.C.; Reynolds, D.J. Seroepidemiology of feline infectious peritonitis virus infections using transmissible gastroenteritis virus as antigen. Zentralblatt für Veterinärmedizin Reihe B 1977, 24, 835-841. [CrossRef] [PubMed]

64. Horzinek, M.C.; Osterhaus, A.D. Feline infectious peritonitis: A worldwide serosurvey. Am. J. Vet. Res. 1979, 40, 1487-1492.

65. Kummrow, M.; Meli, M.L.; Haessig, M.; Goenczi, E.; Poland, A.; Pedersen, N.C.; Hofmann-Lehmann, R.; Lutz, H. Feline coronavirus serotypes 1 and 2: Seroprevalence and association with disease in switzerland. Clin. Diagn. Lab. Immunol. 2005, 12, 1209-1215. [CrossRef]

66. Addie, D.D.; McLachlan, S.A.; Golder, M.; Ramsey, I.; Jarrett, O. Evaluation of an in-practice test for feline coronavirus antibodies. J. Feline Med. Surg. 2004, 6, 63-67. [CrossRef]

67. Pratelli, A. Comparison of serologic techniques for the detection of antibodies against feline coronaviruses. J. Vet. Diagn. Investig. 2008, 20, 45-50. [CrossRef]

68. Pedersen, N.C. The history and interpretation of feline coronavirus serology. Feline Pract. 1995, $23,46-51$.

69. Barlough, J.E.; Stoddart, C.A. Cats and coronaviruses. J. Am. Vet. Med. Assoc. 1988, 193, 796-800.

70. Addie, D.D.; Dennis, J.M.; Toth, S.; Callanan, J.J.; Reid, S.; Jarrett, O. Long-term impact on a closed household of pet cats of natural infection with feline coronavirus, feline leukaemia virus and feline immunodeficiency virus. Vet. Rec. 2000, 146, 419-424. [CrossRef]

71. Addie, D.D.; Jarrett, O. A study of naturally occurring feline coronavirus infections in kittens. Vet. Rec. 1992, 130, 133-137. [CrossRef]

72. Addie, D.D.; Toth, S.; Murray, G.D.; Jarrett, O. Risk of feline infectious peritonitis in cats naturally infected with feline coronavirus. Am. J. Vet. Res. 1995, 56, 429-434.

73. Sparkes, A.H.; Gruffydd-Jones, T.J.; Howard, P.E.; Harbour, D.A. Coronavirus serology in healthy pedigree cats. Vet. Rec. 1992, 131, 35-36. [CrossRef]

74. Scott, F.W. Fip antibody test-interpretation and recommendations. J. Am. Vet. Med. Assoc. 1979, 175, 1164-1168.

75. Gerber, J.D.; Ingersoll, J.D.; Gast, A.M.; Christianson, K.K.; Selzer, N.L.; Landon, R.M.; Pfeiffer, N.E.; Sharpee, R.L.; Beckenhauer, W.H. Protection against feline infectious peritonitis by intranasal inoculation of a temperature-sensitive fipv vaccine. Vaccine 1990, 8, 536-542. [CrossRef]

76. Wasmoen, T.L.; Kadakia, N.P.; Unfer, R.C.; Fickbohm, B.L.; Cook, C.P.; Chu, H.J.; Acree, W.M. Protection of cats from infectious peritonitis by vaccination with a recombinant raccoon poxvirus expressing the nucleocapsid gene of feline infectious peritonitis virus. Adv. Exp. Med. Biol. 1995, 380, 221-228.

77. Haijema, B.J.; Volders, H.; Rottier, P.J. Live, attenuated coronavirus vaccines through the directed deletion of group-specific genes provide protection against feline infectious peritonitis. J. Virol. 2004, 78, 3863-3871. [CrossRef]

78. Hirschberger, J.; Hartmann, K.; Wilhelm, N.; Frost, J.; Lutz, H.; Kraft, W. Clinical symptoms and diagnosis of feline infectious peritonitis. Tierarztliche Prax. 1995, 23, 92-99.

79. Kennedy, M.A.; Abd-Eldaim, M.; Zika, S.E.; Mankin, J.M.; Kania, S.A. Evaluation of antibodies against feline coronavirus $7 \mathrm{~b}$ protein for diagnosis of feline infectious peritonitis in cats. Am. J. Vet. Res. 2008, 69, 1179-1182. [CrossRef]

80. Kennedy, M.A.; Brenneman, K.; Millsaps, R.K.; Black, J.; Potgieter, L.N. Correlation of genomic detection of feline coronavirus with various diagnostic assays for feline infectious peritonitis. J. Vet. Diagn. Investig. 1998, 10, 93-97. [CrossRef]

81. Meli, M.L.; Burr, P.; Decaro, N.; Graham, E.; Jarrett, O.; Lutz, H.; McDonald, M.; Addie, D.D. Samples with high virus load cause a trend toward lower signal in feline coronavirus antibody tests. J. Feline Med. Surg. 2013, 15, 295-299. [CrossRef]

82. Hartmann, K. Feline infectious peritonitis. Vet. Clin. N. Am. Small. Anim. Pract. 2005, 35, 39-79. [CrossRef]

83. Addie, D.; Jarrett, O. Isolation of Immune Complexes in Feline Infectious Peritonitis. In Proceedings of the IXth International Congress of Virology Abstracts, Glasgow, UK, 8-13 August 1993; p. 60.

84. Negrin, A.; Lamb, C.R.; Cappello, R.; Cherubini, G.B. Results of magnetic resonance imaging in 14 cats with meningoencephalitis. J. Feline Med. Surg. 2007, 9, 109-116. [CrossRef] 
85. Addie, D.D.; Jarrett, O. Use of a reverse-transcriptase polymerase chain reaction for monitoring the shedding of feline coronavirus by healthy cats. Vet. Rec. 2001, 148, 649-653. [CrossRef]

86. Addie, D.D.; Schaap, I.A.; Nicolson, L.; Jarrett, O. Persistence and transmission of natural type i feline coronavirus infection. J. Gen. Virol. 2003, 84, 2735-2744. [CrossRef]

87. Soma, T.; Ishii, H. Detection of feline coronavirus antibody, feline immunodeficiency virus antibody, and feline leukemia virus antigen in ascites from cats with effusive feline infectious peritonitis. J. Vet. Med. Sci. 2004, 66, 89-90. [CrossRef]

88. Addie, D.; Belak, S.; Boucraut-Baralon, C.; Egberink, H.; Frymus, T.; Gruffydd-Jones, T.; Hartmann, K.; Hosie, M.J.; Lloret, A.; Lutz, H.; et al. Feline infectious peritonitis. Abcd guidelines on prevention and management. J. Feline Med. Surg. 2009, 11, 594-604. [CrossRef]

89. Lorusso, E.; Mari, V.; Losurdo, M.; Lanave, G.; Trotta, A.; Dowgier, G.; Colaianni, M.L.; Zatelli, A.; Elia, G.; Buonavoglia, D.; et al. Discrepancies between feline coronavirus antibody and nucleic acid detection in effusions of cats with suspected feline infectious peritonitis. Res. Vet. Sci. 2017. [CrossRef]

90. Soma, T.; Saito, N.; Kawaguchi, M.; Sasai, K. Feline coronavirus antibody titer in cerebrospinal fluid from cats with neurological signs. J. Vet. Med. Sci. 2018, 80, 59-62. [CrossRef]

91. Weiss, R.C.; Scott, F.W. Pathogenesis of feline infetious peritonitis: Pathologic changes and immunofluorescence. Am. J. Vet. Res. 1981, 42, 2036-2048.

92. Weiss, R.C.; Scott, F.W. Antibody-mediated enhancement of disease in feline infectious peritonitis: Comparisons with dengue hemorrhagic fever. Comp. Immunol. Microbiol. Infect. Dis. 1981, 4, 175-189. [CrossRef]

93. Paltrinieri, S.; Cammarata Parodi, M.; Cammarata, G.; Comazzi, S. Some aspects of humoral and cellular immunity in naturally occuring feline infectious peritonitis. Vet. Immunol. Immunopathol. 1998, 65, 205-220. [CrossRef]

94. Jacobse-Geels, H.E.; Daha, M.R.; Horzinek, M.C. Isolation and characterization of feline c3 and evidence for the immune complex pathogenesis of feline infectious peritonitis. J. Immunol. 1980, 125, 1606-1610. [PubMed]

95. Jacobse-Geels, H.E.; Daha, M.R.; Horzinek, M.C. Antibody, immune complexes, and complement activity fluctuations in kittens with experimentally induced feline infectious peritonitis. Am. J. Vet. Res. 1982, 43, 666-670.

96. Horzinek, M.C.; Osterhaus, A.D. The virology and pathogenesis of feline infectious peritonitis. Brief review. Arch. Virol. 1979, 59, 1-15. [CrossRef]

97. Weiss, R.C.; Dodds, W.J.; Scott, F.W. Disseminated intravascular coagulation in experimentally induced feline infectious peritonitis. Am. J. Vet. Res. 1980, 41, 663-671.

98. Horzinek, M.C.; Ederveen, J.; Egberink, H.; Jacobse-Geels, H.E.; Niewold, T.; Prins, J. Virion polypeptide specificity of immune complexes and antibodies in cats inoculated with feline infectious peritonitis virus. Am. J. Vet. Res. 1986, 47, 754-761.

99. Pfeiffer, N. Prospects and problems of coronaviral serology. In Proceedings of the Symposium New Perspectives on Prevention of Feline Infectious Peritonitis, Orlando, FL, USA; 1991; pp. 30-34.

100. Schroo, S. Kompetitiver Elisa zum Nachweis von Löslichen Immunkomplexen in Serum und Exsudaten Fip-Verdächtiger Katzen. Ph.D. Thesis, Justus-Liebig-Universität Gießen, Gießen, Germany, 1994.

101. Stoddart, C.A.; Scott, F.W. Intrinsic resistance of feline peritoneal macrophages to coronavirus infection correlates with in vivo virulence. J. Virol. 1989, 63, 436-440.

102. Kipar, A.; Bellmann, S.; Kremendahl, J.; Kohler, K.; Reinacher, M. Cellular composition, coronavirus antigen expression and production of specific antibodies in lesions in feline infectious peritonitis. Vet. Immunol. Immunopathol. 1998, 65, 243-257. [CrossRef]

103. Kipar, A.; May, H.; Menger, S.; Weber, M.; Leukert, W.; Reinacher, M. Morphologic features and development of granulomatous vasculitis in feline infectious peritonitis. Vet. Pathol. 2005, 42, 321-330. [CrossRef]

104. Weiss, R.C.; Scott, F.W. Pathogenesis of feline infectious peritonitis: Nature and development of viremia. Am. J. Vet. Res. 1981, 42, 382-390. [PubMed]

105. Cornelissen, E.; Dewerchin, H.L.; Van Hamme, E.; Nauwynck, H.J. Absence of surface expression of feline infectious peritonitis virus (fipv) antigens on infected cells isolated from cats with fip. Vet. Microbiol. 2007, 121, 131-137. [CrossRef] [PubMed] 
106. Gunn-Moore, D.A.; Gruffydd-Jones, T.J.; Harbour, D.A. Detection of feline coronaviruses by culture and reverse transcriptase-polymerase chain reaction of blood samples from healthy cats and cats with clinical feline infectious peritonitis. Vet. Microbiol. 1998, 62, 193-205. [CrossRef]

107. Kipar, A.; Baptiste, K.; Barth, A.; Reinacher, M. Natural fcov infection: Cats with fip exhibit significantly higher viral loads than healthy infected cats. J. Feline Med. Surg. 2006, 8, 69-72. [CrossRef] [PubMed]

108. Pedersen, N.C.; Liu, H.; Scarlett, J.; Leutenegger, C.M.; Golovko, L.; Kennedy, H.; Kamal, F.M. Feline infectious peritonitis: Role of the feline coronavirus $3 \mathrm{c}$ gene in intestinal tropism and pathogenicity based upon isolates from resident and adopted shelter cats. Virus. Res. 2012, 165, 17-28. [CrossRef] [PubMed]

109. Kipar, A.; Meli, M.L.; Baptiste, K.E.; Bowker, L.J.; Lutz, H. Sites of feline coronavirus persistence in healthy cats. J. Gen. Virol. 2010, 91, 1698-1707. [CrossRef] [PubMed]

110. Addie, D.D.; Paltrinieri, S.; Pedersen, N.C. Recommendations from workshops of the second international feline coronavirus/feline infectious peritonitis symposium. J. Feline Med. Surg. 2004, 6, 125-130. [CrossRef]

111. Hok, K. Demonstration of feline infectious peritonitis virus in conjunctival epithelial cells from cats. A simple and reliable method for clinical veterinary virology screening. Apmis 1989, 97, 820-824. [CrossRef]

112. Walter, J.; Dohse, K.; Rudolph, R. Eine modifikation der abc-methode (avidin-biotin-peroxidase-complex) für den nachweis von viralen antigenen bei der infektion der katze durch ein coronavirus (fip) und der infektion des hundes durch das parvovirus-typ 2. J. Vet. Med. Ser. B 1989, 36, 321-332. [CrossRef]

113. Hok, K. A comparison between immunofluorescence staining on smears from membrana nictitans ( $\mathrm{m} 3$ test), immunohistopathology and routine pathology in cats with suspected feline infectious peritonitis (fip). Acta. Vet. Scand. 1991, 32, 171-176.

114. Hok, K. Demonstration of feline corona virus ( $\mathrm{fcv}$ ) antigen in organs of cats suspected of feline infectious peritonitis (fip) disease. Apmis 1990, 98, 659-664. [CrossRef] [PubMed]

115. Tammer, R.; Evensen, O.; Lutz, H.; Reinacher, M. Immunohistological demonstration of feline infectious peritonitis virus antigen in paraffin-embedded tissues using feline ascites or murine monoclonal antibodies. Vet. Immunol. Immunopathol. 1995, 49, 177-182. [CrossRef]

116. Rissi, D.R. A retrospective study of the neuropathology and diagnosis of naturally occurring feline infectious peritonitis. J. Vet. Diagn. Investig. 2018, 30, 392-399. [CrossRef] [PubMed]

117. Giordano, A.; Paltrinieri, S.; Bertazzolo, W.; Milesi, E.; Parodi, M. Sensitivity of tru-cut and fine needle aspiration biopsies of liver and kidney for diagnosis of feline infectious peritonitis. Vet. Clin. Pathol. 2005, 34, 368-374. [CrossRef]

118. Felten, S.; Hartmann, K.; Doerfelt, S.; Sangl, L.; Hirschberger, J.; Matiasek, K. Immunocytochemistry of mesenteric lymph node fine-needle aspirates in the diagnosis of feline infectious peritonitis. J. Vet. Diagn. Investig. 2019, 31, 210-216. [CrossRef]

119. Dunbar, D.; Kwok, W.; Graham, E.; Armitage, A.; Irvine, R.; Johnston, P.; McDonald, M.; Montgomery, D.; Nicolson, L.; Robertson, E.; et al. Diagnosis of non-effusive feline infectious peritonitis by reverse transcriptase quantitative pcr from mesenteric lymph node fine-needle aspirates. J. Feline Med. Surg. 2018, 1098612x18809165. [CrossRef]

120. Declercq, J.; De Bosschere, H.; Schwarzkopf, I.; Declercq, L. Papular cutaneous lesions in a cat associated with feline infectious peritonitis. Vet. Dermatol. 2008, 19, 255-258. [CrossRef]

121. Bauer, B.S.; Kerr, M.E.; Sandmeyer, L.S.; Grahn, B.H. Positive immunostaining for feline infectious peritonitis (fip) in a sphinx cat with cutaneous lesions and bilateral panuveitis. Vet. Ophthalmol. 2013, 16 (Suppl. 1), 160-163. [CrossRef]

122. Rota, A.; Paltrinieri, S.; Jussich, S.; Ubertalli, G.; Appino, S. Priapism in a castrated cat associated with feline infectious peritonitis. J. Feline Med. Surg. 2008, 10, 181-184. [CrossRef]

123. Stephenson, N.; Swift, P.; Moeller, R.B.; Worth, S.J.; Foley, J. Feline infectious peritonitis in a mountain lion (puma concolor), california, USA. J. Wildl. Dis. 2013, 49, 408-412. [CrossRef]

124. Mwase, M.; Shimada, K.; Mumba, C.; Yabe, J.; Squarre, D.; Madarame, H. Positive immunolabelling for feline infectious peritonitis in an african lion (panthera leo) with bilateral panuveitis. J. Comp. Pathol. 2015, 152, 265-268. [CrossRef] [PubMed]

125. Cammarata Parodi, M.; Cammarata, G.; Paltrinieri, S.; Lavazza, A.; Ape, F. Using direct immunofluorescence to detect coronaviruses in peritoneal and pleural effusions. J. Small Anim. Pract. 1993, 34, 609-613. [CrossRef] 
126. Paltrinieri, S.; Cammarata Parodi, M.; Cammarata, G. In vivo diagnosis of feline infectious peritonitis by comparison of protein content, cytology, and direct immunofluorescence test on peritoneal and pleural effusions. J. Vet. Diagn. Investig. 1999, 11, 358-361. [CrossRef]

127. Felten, S.; Matiasek, K.; Gruendl, S.; Sangl, L.; Wess, G.; Hartmann, K. Investigation into the utility of an immunocytochemical assay in body cavity effusions for diagnosis of feline infectious peritonitis. J. Feline Med. Surg. 2017, 19, 410-418. [CrossRef] [PubMed]

128. Litster, A.L.; Pogranichniy, R.; Lin, T.L. Diagnostic utility of a direct immunofluorescence test to detect feline coronavirus antigen in macrophages in effusive feline infectious peritonitis. Vet. J. 2013, 198, 362-366. [CrossRef] [PubMed]

129. Ives, E.J.; Vanhaesebrouck, A.E.; Cian, F. Immunocytochemical demonstration of feline infectious peritonitis virus within cerebrospinal fluid macrophages. J. Feline Med. Surg. 2013, 15, 1149-1153. [CrossRef] [PubMed]

130. Gruendl, S.; Matiasek, K.; Matiasek, L.; Fischer, A.; Felten, S.; Jurina, K.; Hartmann, K. Diagnostic utility of cerebrospinal fluid immunocytochemistry for diagnosis of feline infectious peritonitis manifesting in the central nervous system. J. Feline Med. Surg. 2017, 19, 576-585. [CrossRef]

131. Jinks, M.R.; English, R.V.; Gilger, B.C. Causes of endogenous uveitis in cats presented to referral clinics in north carolina. Vet. Ophthalmol. 2016, 19 (Suppl. 1), 30-37. [CrossRef]

132. Felten, S.; Matiasek, K.; Gruendl, S.; Sangl, L.; Hartmann, K. Utility of an immunocytochemical assay using aqueous humor in the diagnosis of feline infectious peritonitis. Vet. Ophthalmol. 2018, 21, 27-34. [CrossRef]

133. Li, X.; Scott, F.W. Detection of feline coronaviruses in cell cultures and in fresh and fixed feline tissues using polymerase chain reaction. Vet. Microbiol. 1994, 42, 65-77. [CrossRef]

134. Pedersen, N.C.; Evermann, J.F.; McKeirnan, A.J.; Ott, R.L. Pathogenicity studies of feline coronavirus isolates 79-1146 and 79-1683. Am. J. Vet. Res. 1984, 45, 2580-2585. [PubMed]

135. Barker, E.N.; Stranieri, A.; Helps, C.R.; Porter, E.L.; Davidson, A.D.; Day, M.J.; Knowles, T.; Kipar, A.; Tasker, S. Limitations of using feline coronavirus spike protein gene mutations to diagnose feline infectious peritonitis. Vet. Res. 2017, 48, 60. [CrossRef] [PubMed]

136. Kipar, A.; Meli, M.L.; Failing, K.; Euler, T.; Gomes-Keller, M.A.; Schwartz, D.; Lutz, H.; Reinacher, M. Natural feline coronavirus infection: Differences in cytokine patterns in association with the outcome of infection. Vet. Immunol. Immunopathol. 2006, 112, 141-155. [CrossRef] [PubMed]

137. Porter, E.; Tasker, S.; Day, M.J.; Harley, R.; Kipar, A.; Siddell, S.G.; Helps, C.R. Amino acid changes in the spike protein of feline coronavirus correlate with systemic spread of virus from the intestine and not with feline infectious peritonitis. Vet. Res. 2014, 45, 49-59. [CrossRef] [PubMed]

138. Addie, D.D.; Belák, S.; Boucraut-Baralon, C.; Egberink, H.; Frymus, T.; Gruffydd-Jones, T.; Hartmann, K.; Hofmann-Lehmann, R.; Hosie, M.J.; Lloret, A.; et al. Feline Infectious Peritonitis. Available online: http://www.abcdcatsvets.org/feline-infectious-peritonitis/ (accessed on 8 August 2019).

139. Hornyak, A.; Balint, A.; Farsang, A.; Balka, G.; Hakhverdyan, M.; Rasmussen, T.B.; Blomberg, J.; Belak, S. Detection of subgenomic mrna of feline coronavirus by real-time polymerase chain reaction based on primer-probe energy transfer (p-sg-qpcr). J. Virol. Methods 2012, 181, 155-163. [CrossRef]

140. Freiche, G.M.; Guidez, C.L.; Duarte, M.; Le Poder, Y.B. Sequencing of 3c and spike genes in feline infectious peritonitis: Which samples are the most relevant for analysis? A retrospective study of 33 cases from 2008 to 2014. J. Vet. Intern. Med. 2016, 30, 436.

141. Felten, S.; Emmler, L.; Matiasek, K.; Balzer, H.-J.; Pantchev, N.; Leutenegger, C.M.; Hartmann, K. Detection of mutated and non-mutated feline coronavirus in tissues and body fluids of cats with feline infectious peritonitis. In Proceedings of the 2018 ISCAID Symposium, Portland, OR, USA, 30 September-3 October 2018; p. 76.

142. Sangl, L.; Matiasek, K.; Felten, S.; Grundl, S.; Bergmann, M.; Balzer, H.J.; Pantchev, N.; Leutenegger, C.M.; Hartmann, K. Detection of feline coronavirus mutations in paraffin-embedded tissues in cats with feline infectious peritonitis and controls. J. Feline Med. Surg. 2019, 21, 133-142. [CrossRef]

143. Herrewegh, A.A.; de Groot, R.J.; Cepica, A.; Egberink, H.F.; Horzinek, M.C.; Rottier, P.J. Detection of feline coronavirus rna in feces, tissues, and body fluids of naturally infected cats by reverse transcriptase pcr. J. Clin. Microbiol. 1995, 33, 684-689.

144. Herrewegh, A.A.; Mahler, M.; Hedrich, H.J.; Haagmans, B.L.; Egberink, H.F.; Horzinek, M.C.; Rottier, P.J.; de Groot, R.J. Persistence and evolution of feline coronavirus in a closed cat-breeding colony. Virology 1997, 234, 349-363. [CrossRef] 
145. Egberink, H.F.; Herrewegh, A.P.; Schuurman, N.M.; van der Linde-Sipman, J.S.; Horzinek, M.C.; de Groot, R.J. Fip, easy to diagnose? Vet. Q. 1995, 17 (Suppl. 1), 24-25. [CrossRef]

146. Fehr, D.; Bolla, S.; Herrewegh, A.A.; Horzinek, M.C.; Lutz, H. Detection of feline coronavirus using rt pcr: Basis for the study of the pathogenesis of feline infectious peritonitis (fip). Schweiz. Arch. Tierheilkd. 1996, 138, 74-79. [PubMed]

147. Fish, E.J.; Diniz, P.P.V.; Juan, Y.C.; Bossong, F.; Collisson, E.W.; Drechsler, Y.; Kaltenboeck, B. Cross-sectional quantitative rt-pcr study of feline coronavirus viremia and replication in peripheral blood of healthy shelter cats in southern california. J. Feline Med. Surg. 2018, 20, 295-301. [CrossRef] [PubMed]

148. Simons, F.A.; Vennema, H.; Rofina, J.E.; Pol, J.M.; Horzinek, M.C.; Rottier, P.J.; Egberink, H.F. A mrna pcr for the diagnosis of feline infectious peritonitis. J. Virol. Methods 2005, 124, 111-116. [CrossRef] [PubMed]

149. Doenges, S.J.; Weber, K.; Dorsch, R.; Fux, R.; Hartmann, K. Comparison of real-time reverse transcriptase polymerase chain reaction of peripheral blood mononuclear cells, serum and cell-free body cavity effusion for the diagnosis of feline infectious peritonitis. J. Feline Med. Surg. 2017, 19, 344-350. [CrossRef] [PubMed]

150. Sharif, S.; Arshad, S.S.; Hair-Bejo, M.; Omar, A.-R.; Zeenathul, N.A.; Rahman, N.-A.; Alazawy, A. Evaluation of feline coronavirus viraemia in clinically healthy and ill cats with feline infectious peritonitis. J. Anim. Vet. Adv. 2011, 10, 18-22. [CrossRef]

151. Can-Sahna, K.; Soydal Ataseven, V.; Pinar, D.; Oguzoglu, T.C. The detection of feline coronaviruses in blood samples from cats by mrna rt-pcr. J. Feline Med. Surg. 2007, 9, 369-372. [CrossRef]

152. Ritz, S.; Egberink, H.; Hartmann, K. Effect of feline interferon-omega on the survival time and quality of life of cats with feline infectious peritonitis. J. Vet. Intern. Med. 2007, 21, 1193-1197. [CrossRef]

153. Rottier, P.J.; Nakamura, K.; Schellen, P.; Volders, H.; Haijema, B.J. Acquisition of macrophage tropism during the pathogenesis of feline infectious peritonitis is determined by mutations in the feline coronavirus spike protein. J. Virol. 2005, 79, 14122-14130. [CrossRef]

154. Dewerchin, H.L.; Cornelissen, E.; Nauwynck, H.J. Replication of feline coronaviruses in peripheral blood monocytes. Arch. Virol. 2005, 150, 2483-2500. [CrossRef]

155. Stranieri, A.; Lauzi, S.; Giordano, A.; Paltrinieri, S. Reverse transcriptase loop-mediated isothermal amplification for the detection of feline coronavirus. J. Virol. Methods 2017, 243, 105-108. [CrossRef]

156. Felten, S.; Weider, K.; Doenges, S.; Gruendl, S.; Matiasek, K.; Hermanns, W.; Mueller, E.; Matiasek, L.; Fischer, A.; Weber, K.; et al. Detection of feline coronavirus spike gene mutations as a tool to diagnose feline infectious peritonitis. J. Feline Med. Surg. 2017, 19, 321-335. [CrossRef] [PubMed]

157. Felten, S.; Leutenegger, C.M.; Balzer, H.J.; Pantchev, N.; Matiasek, K.; Wess, G.; Egberink, H.; Hartmann, K. Sensitivity and specificity of a real-time reverse transcriptase polymerase chain reaction detecting feline coronavirus mutations in effusion and serum/plasma of cats to diagnose feline infectious peritonitis. BMC Vet. Res. 2017, 13, 228. [CrossRef] [PubMed]

158. Gamble, D.A.; Lobbiani, A.; Gramegna, M.; Moore, L.E.; Colucci, G. Development of a nested pcr assay for detection of feline infectious peritonitis virus in clinical specimens. J. Clin. Microbiol. 1997, 35, 673-675. [PubMed]

159. Gunther, S.; Felten, S.; Wess, G.; Hartmann, K.; Weber, K. Detection of feline coronavirus in effusions of cats with and without feline infectious peritonitis using loop-mediated isothermal amplification. J. Virol. Methods 2018, 256, 32-36. [CrossRef] [PubMed]

160. Longstaff, L.; Porter, E.; Crossley, V.J.; Hayhow, S.E.; Helps, C.R.; Tasker, S. Feline coronavirus quantitative reverse transcriptase polymerase chain reaction on effusion samples in cats with and without feline infectious peritonitis. J. Feline Med. Surg. 2017, 19, 240-245. [CrossRef]

161. Soma, T.; Wada, M.; Taharaguchi, S.; Tajima, T. Detection of ascitic feline coronavirus rna from cats with clinically suspected feline infectious peritonitis. J. Vet. Med. Sci. 2013, 75, 1389-1392. [CrossRef]

162. Doenges, S.J.; Weber, K.; Dorsch, R.; Fux, R.; Fischer, A.; Matiasek, L.A.; Matiasek, K.; Hartmann, K. Detection of feline coronavirus in cerebrospinal fluid for diagnosis of feline infectious peritonitis in cats with and without neurological signs. J. Feline Med. Surg. 2016, 18, 104-109. [CrossRef]

163. Webb, A.A.; Muir, G.D. The blood-brain barrier and its role in inflammation. J. Vet. Intern. Med. 2000, 14, 399-411. [CrossRef]

164. Felten, S.; Sangl, L.; Matiasek, K.; Leutenegger, C.M.; Pantchev, N.; Balzer, H.-J.; Hartmann, K. Comparison of different diagnostic methods in aqueous humor to diagnose feline infectious peritonitis. In Proceedings of the 2016 ISCAID Symposium, Bristol, UK, 16-19 October 2016. 
165. Denison, M.R.; Graham, R.L.; Donaldson, E.F.; Eckerle, L.D.; Baric, R.S. Coronaviruses: An rna proofreading machine regulates replication fidelity and diversity. RNA Biol. 2011, 8, 270-279. [CrossRef]

166. Kiss, I.; Kecskemeti, S.; Tanyi, J.; Klingeborn, B.; Belak, S. Preliminary studies on feline coronavirus distribution in naturally and experimentally infected cats. Res. Vet. Sci. 2000, 68, 237-242. [CrossRef]

167. Hora, A.S.; Tonietti, P.O.; Taniwaki, S.A.; Asano, K.M.; Maiorka, P.; Richtzenhain, L.J.; Brandao, P.E. Feline coronavirus 3c protein: A candidate for a virulence marker? Biomed. Res. Int. 2016, 2016, 8560691. [CrossRef] [PubMed]

168. Poland, A.M.; Vennema, H.; Foley, J.E.; Pedersen, N.C. Two related strains of feline infectious peritonitis virus isolated from immunocompromised cats infected with a feline enteric coronavirus. J. Clin. Microbiol. 1996, 34, 3180-3184. [PubMed]

169. Borschensky, C.M.; Reinacher, M. Mutations in the $3 \mathrm{c}$ and $7 \mathrm{~b}$ genes of feline coronavirus in spontaneously affected fip cats. Res. Vet. Sci. 2014, 97, 333-340. [PubMed]

170. Bank-Wolf, B.R.; Stallkamp, I.; Wiese, S.; Moritz, A.; Tekes, G.; Thiel, H.J. Mutations of 3c and spike protein genes correlate with the occurrence of feline infectious peritonitis. Vet. Microbiol. 2014, 173, 177-188. [CrossRef] [PubMed]

171. Pedersen, N.C.; Liu, H.; Dodd, K.A.; Pesavento, P.A. Significance of coronavirus mutants in feces and diseased tissues of cats suffering from feline infectious peritonitis. Viruses 2009, 1, 166-184. [CrossRef] [PubMed]

172. Chang, H.W.; de Groot, R.J.; Egberink, H.F.; Rottier, P.J. Feline infectious peritonitis: Insights into feline coronavirus pathobiogenesis and epidemiology based on genetic analysis of the viral 3c gene. J. Gen. Virol. 2010, 91, 415-420. [CrossRef] [PubMed]

173. Hsieh, L.E.; Huang, W.P.; Tang, D.J.; Wang, Y.T.; Chen, C.T.; Chueh, L.L. 3c protein of feline coronavirus inhibits viral replication independently of the autophagy pathway. Res. Vet. Sci. 2013, 95, 1241-1247.

174. Balint, A.; Farsang, A.; Zadori, Z.; Hornyak, A.; Dencso, L.; Almazan, F.; Enjuanes, L.; Belak, S. Molecular characterization of feline infectious peritonitis virus strain df-2 and studies of the role of orf3abc in viral cell tropism. J. Virol. 2012, 86, 6258-6267. [CrossRef]

175. Balint, A.; Farsang, A.; Zadori, Z.; Belak, S. Comparative in vivo analysis of recombinant type ii feline coronaviruses with truncated and completed orf3 region. PLoS ONE 2014, 9, e88758. [CrossRef]

176. Dedeurwaerder, A.; Desmarets, L.M.; Olyslaegers, D.A.; Vermeulen, B.L.; Dewerchin, H.L.; Nauwynck, H.J. The role of accessory proteins in the replication of feline infectious peritonitis virus in peripheral blood monocytes. Vet. Microbiol. 2013, 162, 447-455. [CrossRef]

177. Herrewegh, A.A.; Vennema, H.; Horzinek, M.C.; Rottier, P.J.; de Groot, R.J. The molecular genetics of feline coronaviruses: Comparative sequence analysis of the orf7a/7b transcription unit of different biotypes. Virology 1995, 212, 622-631. [CrossRef] [PubMed]

178. Takano, T.; Tomiyama, Y.; Katoh, Y.; Nakamura, M.; Satoh, R.; Hohdatsu, T. Mutation of neutralizing/antibody-dependent enhancing epitope on spike protein and $7 \mathrm{~b}$ gene of feline infectious peritonitis virus: Influences of viral replication in monocytes/macrophages and virulence in cats. Virus. Res. 2011, 156, 72-80. [CrossRef] [PubMed]

179. Dedeurwaerder, A.; Olyslaegers, D.A.; Desmarets, L.M.; Roukaerts, I.D.; Theuns, S.; Nauwynck, H.J. Orf7-encoded accessory protein $7 \mathrm{a}$ of feline infectious peritonitis virus as a counteragent against ifn-alpha-induced antiviral response. J. Gen. Virol. 2014, 95, 393-402. [CrossRef] [PubMed]

180. Kennedy, M.; Boedeker, N.; Gibbs, P.; Kania, S. Deletions in the 7a orf of feline coronavirus associated with an epidemic of feline infectious peritonitis. Vet. Microbiol. 2001, 81, 227-234. [CrossRef]

181. Lin, C.N.; Su, B.L.; Huang, H.P.; Lee, J.J.; Hsieh, M.W.; Chueh, L.L. Field strain feline coronaviruses with small deletions in orf7b associated with both enteric infection and feline infectious peritonitis. J. Feline Med. Surg. 2009, 11, 413-419. [CrossRef] [PubMed]

182. Heald-Sargent, T.; Gallagher, T. Ready, set, fuse! The coronavirus spike protein and acquisition of fusion competence. Viruses 2012, 4, 557-580. [CrossRef]

183. Bosch, B.J.; van der Zee, R.; de Haan, C.A.; Rottier, P.J. The coronavirus spike protein is a class i virus fusion protein: Structural and functional characterization of the fusion core complex. J. Virol. 2003, 77, 8801-8811. [CrossRef]

184. Jaimes, J.A.; Whittaker, G.R. Feline coronavirus: Insights into viral pathogenesis based on the spike protein structure and function. Virology 2018, 517, 108-121. [CrossRef] 
185. Chang, H.W.; Egberink, H.F.; Halpin, R.; Spiro, D.J.; Rottier, P.J. Spike protein fusion peptide and feline coronavirus virulence. Emerg. Infect. Dis. 2012, 18, 1089-1095. [CrossRef]

186. Licitra, B.N.; Millet, J.K.; Regan, A.D.; Hamilton, B.S.; Rinaldi, V.D.; Duhamel, G.E.; Whittaker, G.R. Mutation in spike protein cleavage site and pathogenesis of feline coronavirus. Emerg. Infect. Dis. 2013, 19, 1066-1073. [CrossRef]

187. Lewis, C.S.; Porter, E.; Matthews, D.; Kipar, A.; Tasker, S.; Helps, C.R.; Siddell, S.G. Genotyping coronaviruses associated with feline infectious peritonitis. J. Gen. Virol. 2015, 96, 1358-1368. [CrossRef] [PubMed]

188. Felten, S.; Leutenegger, C.M.; Balzer, H.J.; Pantchev, N.; Matiasek, K.; Sangl, L.; Doenges, S.; Gruendl, S.; Fischer, A.; Hartmann, K. Evaluation of a discriminative realtime rt-pcr in cerebrospinal fluid for the diagnosis of feline infectious peritonitis. In Proceedings of the 27th ECVIM-CA Congress, St. Julian's, Malta, 14-16 September 2017.

C 2019 by the authors. Licensee MDPI, Basel, Switzerland. This article is an open access article distributed under the terms and conditions of the Creative Commons Attribution (CC BY) license (http://creativecommons.org/licenses/by/4.0/). 